\title{
Using Social Network Analysis to study the Modularity of Protest Forms: The evolution of the Basque Repertoire of Contention (1980-2014)
}

El uso del análisis de redes sociales para estudiar la modularidad de las formas de protesta: la evolución del repertorio vasco de contienda (1980-2014)

\author{
Alejandro Ciordia \\ University of Trento \\ alexciordia@gmail.com (ITALIA) \\ Arkaitz Letamendia \\ University of the Basque Country (UPV/EHU) \\ arkaitz.letamendia@ehu.eus (ESPAÑA)
}

Recibido: 31.05 .2020

Aceptado: 16.06.2021

\begin{abstract}
Demonstrations, strikes, direct actions, and acts of civil disobedience are just a few examples of the broad set of protest tactics potentially available to citizens in order to raise their demands and call the public's attention to unjust situations. Each of these forms of claim-making can be more or less modular. Modularity, a concept originally introduced by Sidney Tarrow (1993) and popularized by Charles Tilly $(1993,1995)$, refers to the adaptability or degree of transferability of protest forms to different circumstances of contention. A protest form is strongly modular when it belongs to the regular repertoire of diverse actors and is employed for the defense of varied issues, against distinct targets, and in different places. Nonetheless, despite the considerable popularity of the concept for theoretical elaboration, its empirical operationalization has so far remained underdeveloped. In this article, building upon the conceptual bases set up by Wada (2012), we lay out a new perspective for the evaluation of the modularity of protest forms. Drawing upon social network analysis, we propose to analyze contingency tables generated from protest event catalogs as two-mode networks,
\end{abstract}


measuring tactical transferability as weighted degree centrality (Opsahl et al. 2010). To demonstrate the usefulness of our proposed operationalization, we examine a large original dataset of protest events, applying our measure in order to evaluate repertoire change in the Basque Country over the last four decades, tracing the evolution of ten different protest forms in terms of actor transferability. Results show a relatively rigid repertoire in which demonstrations appear as dominant, at the same time that symbolic protests have gradually increased its modularity in recent years, at the expense of civil disobedience and violent direct action, which used to be significantly more relevant during the 80s and 90s. In comparison with Wada's original proposal, the new measure of modularity proposed in this article derives from a more intuitive operationalization and offers an easily interpretable visual representation of the data. These advantages could eventually encourage more empirical research comparing the varying modularity of forms of contention across diverse contexts and periods.

\section{KEY WORDS}

Repertoire of contention, modularity, social network analysis, protest event analysis, Basque Country.

\section{RESUMEN}

Manifestaciones, huelgas, acciones directas, o actos de desobediencia civil forman parte de un amplio abanico de tácticas de protesta mediante las cuales la población plantea demandas a pie de calle. Cada una de estas formas de acción reivindicativa puede ser más o menos modular. La modularidad, concepto introducido originalmente por Sidney Tarrow (1993) y popularizado por Charles Tilly $(1993,1995)$, hace referencia a la capacidad de adaptación, o grado de transferibilidad, de cada forma de protesta a diferentes contextos. Es decir, un modo de protesta presenta una alta modularidad si forma parte del repertorio habitual de diversos actores y es utilizado para diferentes causas, contra distintos destinatarios y en múltiples lugares. Sin embargo, el amplio desarrollo teórico del concepto no ha ido acompañado de un desarrollo similar en su operacionalización empírica. En este trabajo, partiendo de la base conceptual desarrollada por Wada (2012), planteamos una nueva perspectiva desde la que evaluar la modularidad de las formas de protesta. Así, a través del análisis de redes sociales, proponemos analizar las tablas de contingencia generadas a partir de catálogos de eventos de protesta como redes bimodales de afiliaciones, midiendo la transferibilidad de las diferentes tácticas como la centralidad de grado ponderada (Opsahl et al. 2010). Para ilustrar la utilidad de nuestra propuesta de operacionalización, utilizamos una base de datos original de eventos de protesta, aplicando nuestra medida para describir los principales cambios en el repertorio vasco de contienda durante las últimas cuatro décadas, siguiendo la evolución de la trans- 
feribilidad entre actores de diez formas de protesta diferentes. Los resultados del estudio revelan un repertorio relativamente rígido dominado por las manifestaciones y en el que la protesta simbólica ha ido adquiriendo progresivamente una mayor modularidad, a costa de la desobediencia civil y la acción directa violenta, que gozaban de mayor relevancia en los años 80 y 90 . En conclusión, la nueva medida propuesta en este artículo ofrece una operacionalización más intuitiva y fácilmente representable visualmente respecto a la propuesta inicial de Wada, lo que podría incentivar la realización de más investigaciones empíricas que comparen las características de los repertorios de contienda en diferentes contextos políticos y/o periodos históricos.

\section{PALABRAS CLAVE}

Repertorio de contienda, modularidad, análisis de redes sociales, análisis de eventos de protesta, Euskal Herria.

\section{INTRODUCTION: REPERTOIRES OF CONTENTION AND THE NOTION OF MODULARITY}

Demonstrations, strikes, direct actions, and acts of civil disobedience are just a few examples of the broad set of protest tactics potentially available to citizens in order to raise their voices and call the public's attention to unjust situations. The entire stock of protest forms available in a given polity during a certain period constitute a repertoire of contention (Tilly 1979, 1993, 1995, 2006, 2008). The most interesting feature of tactical repertoires is that they can be studied from both a cultural and a structural perspective (Tarrow 1998: 30). On the one hand, any given repertoire is a "learned cultural creation" emerging from the political struggle, as it comprises a limited set of protest forms, or "routines", that political actors are familiar with (Tilly 1995: 42). At the same time, repertoires are part of the opportunity structure conditioning actors' behavior, given that existing repertoires "constrain the choices available for collective action" (Ibid.).

It is important to emphasize that repertoires are historically contingent and often exhibit a marked local character, due to their tight interdependence with the political and sociocultural context in which contention takes place. Actors' tactical choices depend on many contextual and historically specific factors, such as what is repressed or permitted, what is morally acceptable or reprehensible, or what generates attention or goes unnoticed. Since the changing characteristics of repertoires in different polities and/or periods are to a large extent a reflection of prevailing political regimes and cultures (Ring-Ramirez et al. 2014; Tilly 2006), the study of repertoires of contention can be extremely valuable as a way of obtaining new insights about the dominant structural and cultural patterns within a polity in a certain period (Doherty \& Hayes 2019: 271-2). 
A crucial task for the comparison of repertoires of contention -whether cross-sectional or longitudinal- is to identify the different protest forms that compose them and assess their relative importance. Precisely, evaluating the relevance of each tactic vis-a-vis other available alternatives becomes crucial for the characterization of repertoires. For instance, where orderly demonstrations and institutional petitions are the preferred forms of protest and more confrontational tactics like acts of civil disobedience or even violence are peripheral, we could speak of a relatively contained or conventional repertoire. On the contrary, in more radical or belligerent repertoires, the latter sets of tactics would play a more important role.

Apart from the nature of the most popular protest forms, we could also describe a repertoire in terms of how varied the range of core tactics is and how much space for innovation is left. That is, how flexible or rigid repertoires are (Tilly 2006: 39-41; 2008: 15-19). For instance, the model of "social movement societies", which according to Meyer and Tarrow (1998) was hegemonic in Western polities at the turn of the millennium, is an archetypical case of a rigid repertoire where very few forms of protests -authorized demonstrations, and to a lesser extent, strikes- are employed, with protest becoming routinized. In contrast, at the peak of an intense protest cycle (Tarrow 1998) repertoires tend to become more flexible, as successful campaigns normally generate tactical innovations, even to the point of introducing new innovative protest forms within the existing repertoire.

That said, how can we exactly observe the prominence of each protest form in a given repertoire and then analyze its evolution over time or across contexts? A common approach has been to collect large catalogs of protest events, categorize the tactics deployed at these contentious gatherings, and count their frequencies. However, we contend that the relative prominence of a given protest form within a repertoire should not only be assessed by how much it is used, its incidence, but rather by how modular it is. Modularity, a concept originally introduced by Sidney Tarrow (1993), refers to the adaptability or degree of transferability (Wada 2012) of protest forms to different circumstances of contention. That is to say, a protest form is strongly modular when it belongs to the regular repertoire of diverse actors, is employed for the defense of varied claims, against distinct targets, and in different places (Ibid.). In other words, a protest form is said to be modular when it shows the "capacity for tactical travel" (Doherty \& Hayes 2019: 272) across very different users, issues, targets and locations. Nonetheless, despite the considerable popularity of the concept of modularity for theoretical elaboration, its empirical operationalization has so far remained underdeveloped.

This article aims to contribute to this development by proposing a new way of studying the modularity of protest forms in different temporal or geographic contexts, based on the combination of protest event data and network-analytic techniques. The next section begins by discussing in depth the major contribution of Takeshi Wada (2012) to the conceptualization and measurement of modularity, after which we present our own network-based approach. Then, we 
briefly introduce the data employed for the empirical illustration of our proposal, a large original catalog of protest events that allows us to conduct a longitudinal analysis of changes in the Basque Country's repertoire of contention between 1980 and 2014. After describing this dataset, the main results of our modularity analysis are presented and discussed. Finally, the last section discusses several potential contributions of this article, both in methodological and substantive terms.

\section{CONCEPTUALIZING AND MEASURING MODULARITY: WADA'S PROPOSAL}

As already mentioned above, the fact that modularity belongs nowadays to the mainstream conceptual toolkit of social movement scholars contrasts with the lack of proper empirical operationalization of the concept. Indeed, it was not until a few years ago that Takeshi Wada (2012) proposed a specific empirical measure of modularity. Wada conceptualizes modularity as "the degree of transferability of a contentious form across different contentious contexts" (Ibid.: 546). Furthermore, he states that for a complete assessment of modularity, at least four realms of these contentious contexts should be explicitly addressed: actors, targets, issues, and geographic locations. To be consistent with the original formulation of Tarrow (1993) and Tilly (1993, 1995), an ideal modular form of contention should not only be highly transferable in one of the dimensions, but in all of them, being "used by a variety of actors, against a variety of targets, for a variety of issues, and at a variety of locations" (Wada 2016: 450; see also Wada 2012: 548).

At this point we should warn the reader that in this article we will mainly focus on just one of these four dimensions, actor transferability, as we find it to be the easiest to grasp for a first approximation to the proposed measure. Therefore, as our aims are more methodological than substantive, the hypothetical examples and real-world data that we will use to illustrate our approach to modularity will exclusively focus on actor transferability. Researchers interested in a comprehensive assessment of modularity that takes into account all four types of transferability would only need to repeat the procedure that will be explained below to data containing information on issues, targets, and locations, and finally compute the average of the four dimensions of transferability. Having made this clarification, in the remainder of this article we will follow Wada (2012) in using the terms "modularity" and "transferability" interchangeably.

Another crucial and insightful element of Wada's conceptualization refers to his distinction between two aspects into which transferability can be broken down and separately assessed: breadth and depth (2012: 556-7). Breadth, probably the most intuitive of the two, refers to the degree of reachability or diffusion, which is a function of the proportion of actors that adopt a certain tactic. However, transferability cannot be measured exclusively by breadth, but it is also necessary to examine the intensity of this usage. For instance, tactics can be either 
fully adopted by an actor in all of their actions, or rather, very occasionally, or even just once. When a protest form is residually employed by actors using it, it would not make sense to assign the same score of transferability to a tactic that is adopted by the same set of actors (same breadth) but that constitutes their preferred tactical choice. The latter is certainly more modular than the former. The different degrees of adoption, familiarity, or mastery of the tactics by those that deploy certain protest forms is captured by the concept of depth. The combination of these two aspects in a bidimensional space can help us distinguish different ideal types of tactics from the perspective of modularity, which are displayed below in figure $1 .^{1}$

\section{Figure 1. Ideal types of protest forms from the perspective of modularity}

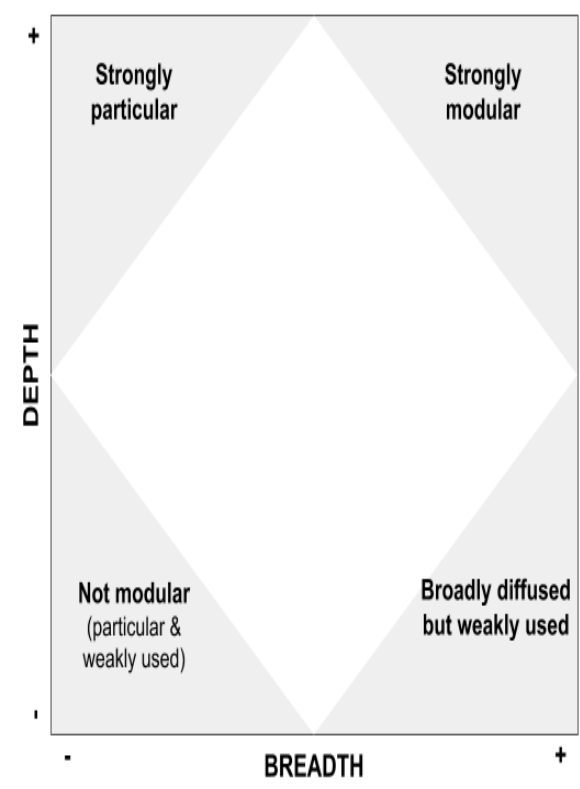

(source: own elaboration, based on Wada 2012: 559)

${ }^{1}$ It should be noted that we decided not to use exactly the same labels originally used by Wada. While we kept the labels "strongly modular" and "strongly particular", we substituted the two at the bottom of the chart, as we found Wada's original formulations to be potentially misleading. More specifically, "non modular" replaced what he named "weakly particular" tactics, and the long category of "broadly diffused but weakly used" replaced his original "weakly modular" label. 
Once defined and conceptualized, how can we measure transferability? Wada's operationalization builds upon the computation of two distributional statistics: Gini coefficients and means. ${ }^{2}$ In order to better explain Wada's proposed scores, we can examine a simple hypothetical example. Let's imagine a dataset with observations of 600 protest events in which we have recorded information about the predominant form of contention employed (our main object of interest) and the type of actors organizing the protest. Tables 1 and 2 summarize the distributions of events across five hypothetical forms of protest (A through E) and five types of actors (students, industrial workers, environmentalists, feminists, and farmers). While table 1 displays absolute frequencies, the relational perspective needed for studying modularity as transferability requires to transform these raw values in relative frequencies, as shown in table 2, with cell values corresponding to row-wise proportions. By using the contingency table of relative frequencies as input for subsequent analyses we are able to focus entirely on the preference of actors for certain tactics over others, getting rid of quantitative distortions generated by protest cycles or actors' unequal mobilization capacities and resources, which are quite marked in this example as well as in most realworld data. In other words, this simple transformation allows us to disentangle the modularity of protest forms from their overall incidence.

Table 1. Contingency table of hypothetical event dataset, absolute frequencies

\begin{tabular}{ccccccc}
\hline & \multicolumn{7}{c}{ Protest Forms } & \multirow{2}{*}{ Total } \\
\cline { 2 - 6 } Type of Actors & $\mathrm{A}$ & $\mathrm{B}$ & $\mathrm{C}$ & $\mathrm{D}$ & $\mathrm{E}$ & \\
\hline & & & & & & \\
Students & 112 & 14 & 0 & 0 & 14 & 140 \\
Industrial workers & 0 & 76 & 114 & 152 & 38 & 380 \\
Environmentalists & 0 & 0 & 0 & 10 & 10 & 20 \\
Feminists & 0 & 4 & 0 & 28 & 8 & 40 \\
Farmers & 0 & 2 & 0 & 14 & 4 & 20 \\
& & & & & & \\
Total & 112 & 96 & 114 & 204 & 74 & 600 \\
\hline
\end{tabular}

2 As Wada summarizes: "The Gini coefficient is a popular measure of income distribution inequality. The Gini coefficient is a ratio between 0 and 1. In a society where income is distributed equally among its members, the Gini coefficient is 0 . In contrast, in a society where income is distributed in the most unequal manner (e.g., one member monopolizes all the income in that society), the Gini coefficient is 1" (Wada 2012: 557). In order to apply the Gini coefficient to, say, actor transferability, we need to consider the set of actors' categories as our population and the percentage of protest events in which each form of contention is employed as the income. 
Table 2. Contingency table of hypothetical event dataset, relative frequencies by row

\begin{tabular}{cccccc}
\hline & \multicolumn{5}{c}{ Protest Forms } \\
\cline { 2 - 6 } Type of Actors & $\mathrm{A}$ & $\mathrm{B}$ & $\mathrm{C}$ & $\mathrm{D}$ & $\mathrm{E}$ \\
\hline & & & & & \\
Students & .8 & .1 & 0 & 0 & .1 \\
Industrial workers & 0 & .2 & .3 & .4 & .1 \\
Environmentalists & 0 & 0 & 0 & .5 & .5 \\
Feminists & 0 & .1 & 0 & .7 & .2 \\
Farmers & 0 & .1 & 0 & .7 & .2 \\
& & & & & .33 \\
Gini coefficient (a) & .80 & .32 & .80 & .30 & .22 \\
Mean usage (b) & .16 & .10 & .06 & .46 & \\
\hline
\end{tabular}

Table 2 provides all the elements necessary to compute the breadth, depth and actor transferability scores. As mentioned above, Wada's distribution-based measures of modularity require to compute two basic statistics for each column vector, which are also reported in table 2: the Gini coefficient and the mean usage percentage across all actors (including also non-users in the calculation). Regarding breadth, Wada proposes to measure it as the reversed score of the Gini coefficient $(1-a)$. This way, the more evenly a certain form of contention is used across the range of actors considered, the closer the Gini coefficient gets to zero, and therefore, the closer the breadth score gets to 1 . In the case of depth, it is measured as the average usage of each form of contention across all actors, normalized by its breadth $(\mathrm{b} / 1-\mathrm{a})$. Finally, the overall measure of actor transferability is simply the average of the breadth and depth scores. Table 3 below reports the resulting scores of actor transferability for the five hypothetical protest forms considered in the example.

Table 3. Wada's actor transferability scores of five hypothetical protest forms

\begin{tabular}{ccccc}
\hline Protest form & Transferability & Rank & Breadth & Depth \\
A & .50 & 2 & .20 & 0.80 \\
B & .41 & 4 & .68 & 0.15 \\
C & .25 & 5 & .20 & 0.30 \\
D & .68 & 1 & .70 & 0.65 \\
E & .50 & 2 & .67 & 0.33 \\
\hline
\end{tabular}

When comparing the actor transferability of each protest form to their aggregative incidence displayed above in table 1, we can note how these two features do not always go hand in hand. While form $\mathrm{D}$ is both the most frequent and the most modular tactic, the transferability of forms $\mathrm{C}$ and $\mathrm{E}$ contrasts sharply with 
their quantitative incidence. Despite the fact that form $\mathrm{E}$ is the least frequent protest form in the dataset, being employed only in $12 \%$ of the recorded events, it ties form A as the second most modular, mainly due to the fact that it is the only tactic employed by all five actor types, which provides a high breadth score. On the other hand, even though form $\mathrm{C}$ is deployed in 40 more events than form $\mathrm{E}$, only industrial workers resort to it, yet without making it its preferential tactical choice either, as workers employ it in just every 3 out of 10 of their events.

This conceptualization of modularity as transferability, and its operationalization through formulas that use distributional statistics to obtain comparable transferability scores opens many interesting possibilities for empirical research on repertoires of contention. Having a quantitative measure of modularity allows to systematically compare repertoires in different geographies, as well as to describe more precisely repertoire change over time in a single society. In either case, modularity scores could be used either as a dependent or independent variable in order to test, respectively, different theories on the causes of tactical innovations or the varying incidence of different types of protest on political outcomes (Ibid.: 568). Moreover, Wada's conceptualization of modularity and his proposal for operationalization can help avoid two potential misconceptions in the use of the notion of modularity.

First, modularity has often been treated as an inherent property of some protest forms, assuming a priori that some forms are modular and others are not (Ibid.: 546). This is certainly the result of the popularization of Tilly's work (1993, 1995), which incorporated Tarrow's (1993) concept in his historical account of how the modern repertoire of contention characterized by public meetings, petitions and demonstrations first emerged in Britain during the second half of the 18th century and the beginning of the 19th century. This modern repertoire replaced a pre-modern eighteenth-century one characterized by locallyspecific mob actions and riots marked by relatively spontaneous acts of violence, forms which were quite particular, in the sense of "having highly differentiated forms of action for different groups, situations, and localities" (Tilly 2008: 43). In contrast, the main components of the modern repertoire were modular, "being easily transferable from one setting or circumstance to another instead of being shaped tightly to particular uses" (Ibid.: 45). Thus, Tarrow, Tilly and many others after him (e.g. Cruz 2008, 2015) used the concept of modularity in a rather static and essentialist fashion, as an inherent property of certain forms, as if demonstrations did not acquire modularity at a particular historical conjuncture but instead had always been modular from the start, even before they became broadly employed. Later studies devoting special attention to diffusion processes have reinterpreted the initial static formulations of the modularity concept in more dynamic terms, emphasizing that tactics are not essentially modular but rather become so (see Doherty \& Hayes 2019: 272-3; Soule 2004: 300). ${ }^{3}$

${ }^{3}$ For instance, along these lines, Itçaina (2017) has recently problematized the clear-cut distinction between the pre-modern particularistic repertoire and the modern modular one. Drawing upon the examination of several case studies of popular protest in Western Europe, the author 
Secondly, even when modularity is analyzed in dynamic and inductive terms, either relying on historical narratives or on event counts, one could be tempted to assume that the modularity of a single protest form could be studied by assessing its quantitative incidence over time and/or in comparison with other tactics. (e.g. Biggs 2013; López-Maya 2002; McPhail 2013: 759) This aggregative approach betrays a key aspect of the concept of modularity as transferability of forms of action in different contexts: its relationality. Despite the fact that the most frequently employed forms of action also tend to be the most modular (as it is the case of demonstrations in most contemporary Western contexts), any rigorous analysis should take into consideration that more often does not always mean more modular, as a high frequency of a given protest form could derive from repetition by a limited set of actors, instead of by its adoption by a wide and heterogenous set of protestors. For instance, we can imagine how at the height of a radicalized conflict, riots and attacks against property might become extremely common, outnumbering other more orderly forms of protests such as marches or rallies. Still, if only a very limited set of collective actors is behind these riots it would be wrong to conclude that rioting has become a strongly modular form of contention, since its levels of breadth (its diffusion) remain minimal, at least with respect to the realm of actors.

\section{ADOPTING A NETWORK APPROACH: TRANSFERABILITY AS WEIGHTED DEGREE CENTRALITY}

Having outlined the potentialities of Wada's proposed measures of modularity, we would like to present another way of operationalizing the notion of modularity. While our operationalization is essentially complementary to Wada's original proposal and we largely build upon his groundbreaking conceptual work, we believe our network-based measurement can help overcome some limitations of the original one. In our opinion, the lack of an adequate graphic representation of the association between protest forms on the one side, and actors, targets, issues, or locations on the other, added to the central role played by the Gini coefficient, might have caused Wada's operationalization to be regarded as excessively complex and scarcely appealing. In other words, these features are likely to have hindered the diffusion of his novel quantitative operationalization among social movement analysts interested in modular repertoires of contention. Precisely, our proposal aims to overcome these drawbacks, providing a methodological tool that may hopefully be attractive to other researchers interested in evaluating the modularity of different tactics and their cross-country

stresses how contemporary protest repertoires in the 20th century continued to be strongly influenced by inherited traditions and protest forms strongly intertwined with local popular cultures. The insights that emerge from such historical examinations calls into question the extended essentialist conception of modularity as an inherent property of certain protest forms such as demonstrations. 
and temporal variations, an exciting line of inquiry that still remains largely unexplored. Moreover, we believe that the conceptual and methodological toolkit of social network analysis (SNA) is particularly suitable to grasp the inherent relational nature of the notion of modularity.

Essentially, we propose to look at the normalized contingency table that serves as input data (see table 2) as a two-mode network matrix, that is, as a network composed of two different sets of entities where only connections between nodes belonging to different sets are allowed. In this case, the data from our hypothetical example can be conceived as a network where protest forms are connected to the types of actors that make use of them, and vice versa. Since these connections are reciprocal and present a varying strength, this type of network is undirected and weighted. Figure 2 displays this bipartite graph for the previous example, with modes differentiated by color (black for protest forms and white for actors) and edge widths being proportional to the strength of ties, which is the result of actors' relative usage of a tactic. Additionally, to facilitate the contrast between modularity and aggregative incidence, node sizes are scaled according to the number of events in which each protest form was adopted or, alternatively, that each type of actor organized.

\section{Figure 2. Bipartite graph of protest forms and actor types, hypothetical event} dataset

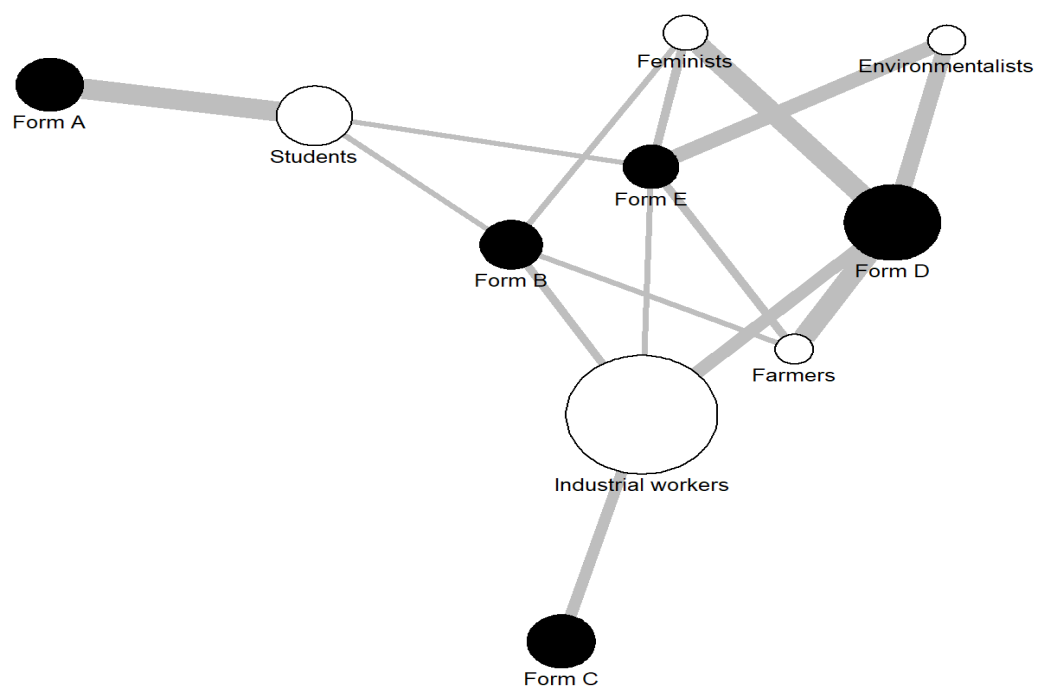

(source: own elaboration) 
Besides providing a neat and easily interpretable graphic representation of the data, the adoption of a network-analytic perspective can help us think about transferability in a new way: as node centrality. The task of identifying which nodes are more central than others in a network has long been one of the key concerns of network analysts (see Bonacich 1987; Freeman 1978). Basically, centrality enables the analyst to study the importance of every node in terms of its structural position within the network. Depending on the substantive nature of the data and how "importance" is conceptualized, centrality can be used to study a wide variety of crucial properties of the individual units that constitute a network, such as power, intermediation capacity, popularity, or access to resources, among many others. In this case, we contend that node centrality can be extremely useful to study the transferability of protest forms. Among the many different formal conceptualizations that exist within the "family of concepts" related to centrality (Borgatti et al. 2013: 164), degree centrality -the most popular and intuitive of all- can be especially illuminating. Degree centrality focuses on the degree of involvement of a focal node with others, considering only its local structure, that is, its immediate neighbors. Applying the notion of degree centrality to the purpose of measuring tactical modularity, the basic idea is that the more involved a protest form is with other nodes in the bipartite network, the more important or central that tactic is from a relational point of view, and, consequently, the more transferable it is.

Since node centrality was initially formalized by Freeman (1978) for unweighted or binary networks (those in which ties are either present or absent but do not have values associated with them) the simplest version of degree centrality only considers the number of ties a node has. For instance, in figure 2, forms $A$ and $C$ present a raw degree of 1 , forms of $B$ and $D$ of 4 , and form $E$ a degree of 5 , which is the maximum for this graph. However, attention to the number of ties of a protest form only reveals one of the two aspects of transferability: breadth. From a network-analytic perspective, we can operationalize breadth as the normalized raw degree of nodes, that is, the observed number of ties to other elements (types of actors in this case) divided by the maximum possible number of connections that could potentially be established (five in this case). In contrast, for the study of weighted networks, some authors have proposed to reformulate degree centrality as the sum of weights (Barrat et al. 2004; Newman 2004; Opsahl et al. 2008), a measure labelled as node strength. However, it should be noted that "node strength is a blunt measure as it only takes into consideration a node's total level of involvement in the network, and not the number of other nodes to which it connected" (Opsahl et al. 2010: 246). Nonetheless, its sole focus on the intensity of the connections, regardless of their number, fits very well with the other aspect of transferability: depth. From a network perspective, we propose to measure depth as the average strength of observed ties. In other words, depth can be calculated as total node strength divided by breadth. ${ }^{4}$

${ }^{4}$ This "average strength of observed ties" should not be confused with the "mean usage" reported in table 2, which Wada uses as the numerator of his formula to calculate depth. The latter 
Thus, our measure of depth in the case of nodes with a raw degree of 1 (forms A and $\mathrm{C}$ in our hypothetical example) matches the score obtained from Wada's formula (.8 and .3 , respectively). However, when looking at the other three nodes, our depth score differs slightly from Wada's, showing lower values, as it can be observed below when contrasting the two depth columns in table 4.

In the previous paragraph we have seen how the two most extended formalizations of degree centrality can help us operationalize the two aspects into which transferability can be broken down. While degree centrality as the simple count of ties serves as a straightforward indicator of breadth, total node strength -once controlled by degree- can be used to assess the depth of a protest form. In our opinion, these network-based measures are simpler and more intuitive than Wada's formulas, to the point that in small networks, such as the one resulting from our example, calculations can even be made directly by hand.

However, the reader might be wondering whether it is completely necessary, or even desirable, to operate in two steps, as proposed by Wada, first computing separate measures of breadth and depth and then assuming transferability to be the average of the two scores. It is certainly not very efficient in practical terms, especially if dealing with very large datasets or whenever the analyst is only interested in overall levels of transferability but not on a closer examination of how breadth and depth combine. Fortunately, the assessment of node centrality in weighted networks has been refined over the last decade thanks to a new measure introduced by Opsahl, Agneessens, and Skvoretz (2010). Their encompassing measure of weighted degree centrality $\left(C_{D}^{w \propto}\right)$ "is the product of the number of nodes that a focal node is connected to, and the average weight to these nodes" ( $k_{i}$ and $s_{i}$, respectively), adjusted by a tuning parameter $(\alpha)$ that "determines the relative importance of the number of ties compared to tie weights" (Ibid.: 246-7). Their measure is thus formalized as follows:

$$
\text { [1] } C_{D}^{w \propto}(i)=k_{i} \times\left(\frac{s_{i}}{k_{i}}\right)^{\propto}=k_{i}^{(1-\propto)} \times s_{i}^{\alpha}
$$

When the tuning parameter is set between 0 and 1 , increments in either the number of ties or the total node strength have a positive impact on the resulting centrality score (Ibid.: 250). The application of this measure of weighted degree centrality to our special two-mode networks of protest forms and type of actors allows us to simultaneously take into account both the breadth and depth of every single protest form, being able to produce a measure of overall transferability in a single step. Still, in case the analyst is interested in further exploring the breadth and depth of every protest form, the unweighted degree and the total

results from dividing the total sum of weights by all categories of actors, including both users and non-users, while we only take into account actors that employ a given protest form at least once. 
strength of each node is automatically reported as well, so separate measures of breadth and depth can be easily calculated from them.

That said, the aforementioned original measure of weighted degree centrality presents one minor flaw: the fact that it is insensitive to variation in tie weights. Sensitivity to variations in tie weights is particularly important for measuring transferability, as it allows to incorporate the equality or inequality of usage levels across actors, which was a major focus in Wada's operationalization and seems to have motivated his use of the Gini coefficient. For this reason, we adopted an alternative version of the weighted degree centrality measure that was developed by Opsahl (2011)a year later. This slightly modified measure of weighted degree centrality $\left(C_{D}^{w 2 \alpha}\right)$ provides very similar results though it incorporates this factor in the final score. This is done hv powering each sing le tie weight $\left(w_{i j}\right)$ to $\alpha$ instead of the average tie weight $\left(\frac{s_{i}}{k_{i}}\right)$. Its formal definition is as follows:

$$
\text { [2] } C_{D}^{w 2 \alpha}(i)=\sum_{J}^{N} w_{i j}^{\alpha}
$$

Basically, when $0<\alpha<1$ and both the number of ties and the total strength are held constant, the node presenting a more equal distribution of tie weights is favored and obtains a slightly higher centrality score (for further details, see: Opsahl 2011). ${ }^{5}$ Calculations were conducted by using the R-package thet with Opshal's function instead of the default degree_w function, setting the value of $\triangle$ at 0.5 for the sake of simplicity, following Opsahl et al. (2010). The resulting scores are reported below in table 4, while the original code script is also available upon request.

A quick look at table 4 reveals that scores derived from our operationalization of actor transferability as the weighted degree centrality of each protest form are remarkably similar to the ones obtained from Wada's operationalization. This is a good sign in terms of the validity of our measure, since we aim to operationalize the same concept that was theoretically delineated by Wada, though following a different logic that, in our opinion, can be more intuitive and appealing to many researchers.

${ }^{5}$ Because of this property, another additional advantage of Opsahl's alternative measure is that it partially mitigates the potentially damaging impact of inflated average tie weights caused by outliers (e.g. actors involved in few events but displaying an exceptionally large usage proportion of a certain protest form) in artificially raising overall transferability scores. 
Table 4. Network-based transferability scores of five hypothetical forms

\begin{tabular}{|c|c|c|c|c|c|c|c|c|}
\hline \multirow[b]{2}{*}{$\begin{array}{l}\text { Protest } \\
\text { form }\end{array}$} & \multicolumn{4}{|c|}{ Network-based operationalization } & \multicolumn{4}{|c|}{ Wada's operationalization } \\
\hline & $\begin{array}{l}\text { Transfe- } \\
\text { rability }\end{array}$ & Rank & Breadth & Depth & $\begin{array}{l}\text { Transfe- } \\
\text { rability }\end{array}$ & Rank & Breadth & Depth \\
\hline A & .18 & 4 & .20 & .80 & .50 & 2 & .20 & 0.80 \\
\hline B & .28 & 3 & .80 & .12 & .41 & 4 & .68 & 0.15 \\
\hline $\mathrm{C}$ & .11 & 5 & .20 & .30 & .25 & 5 & .20 & 0.30 \\
\hline $\mathrm{D}$ & .60 & 1 & .80 & .57 & .68 & 1 & .70 & 0.65 \\
\hline $\mathrm{E}$ & .45 & 2 & 1 & .22 & .50 & 2 & .67 & 0.33 \\
\hline
\end{tabular}

The most noticeable divergence can be observed in the case of protest form A, which according to Wada's procedure was the second most transferable tactic, tied with form $\mathrm{E}$ and above form B. In contrast, from a network perspective, its weighted degree centrality places it in fourth position. This underlines an important feature that differentiates our transferability measure from Wada's proposal: despite simultaneously taking into account both the diffusion and the usage intensity of a certain protest form, its final score does not correspond to the exact average of breadth and depth. That is, although increments in either two aspects lead to higher weighted degree centrality scores, their respective contribution is not symmetrical. When the value of $\alpha$ is set at 0.5 , the final transferability score is slightly more influenced by the indicator of breadth (number of ties) than by the indicator of depth (node strength). This explains for instance the fact that form B gets a higher transferability score than form A.

This divergence is not necessarily negative, as we do not seek to exactly replicate Wada's measure but to offer an alternative to it. Even though this feature was not purposely sought from the start by these authors, we believe this unequal weight of breadth and depth might be actually more coherent with the initial theoretical formulations of modularity. In fact, in his original introduction and discussion of the concept, Tarrow (1993) seemed to almost equate transferability with diffusion. While we agree with Wada's warning that "transferability cannot be measured exclusively by breadth" (2012: 556), a point we consider to be crucial for the refinement of the concept of modularity, we question his assumption that both aspects should have the same weight. Of course, this is an open theoretical question that cannot be addressed here, but the key advantage of operationalizing transferability as weighted degree centrality is that, just by adjusting the tuning parameter $\alpha$ at different values between 0 and 1 , this measure can be used under different theoretical assumptions regarding the relative importance of breadth and depth for assessing modularity. Those who side with our claim that breadth should be more influential than depth for the evaluation of modularity could set the value of $\alpha$ at 0.5 , or even less if they would like to further increase the weight of breadth over depth. On the contrary, those who would 
like a perfectly balanced weight of degree and node strength should increase the tuning parameter and devise some robust criteria to inductively find the optimal value of $\alpha$ that fits their purpose. Indeed, as the network analysts that developed the measure of weighted degree centrality already pointed out, determining "the exact value of a to use" for different particular purposes remains "an area of potential research" on its own (Opsahl et al. 2010: 250).

\section{DATA: PROTEST EVENTS IN THE BASQUE COUNTRY}

In order to illustrate our methodological proposal with real-world data, in the remainder of this article we analyze the evolution of the actor transferability of ten different protest forms in the Basque Country between 1980 and 2014. Why the Basque Country? Apart from practical considerations of data availability, we contend that two main features make this territory a particularly suitable and interesting case study for the analysis of repertoires of contention and their evolution over time. ${ }^{6}$

The first and most important characteristic refers to the high levels of sociopolitical mobilization and protest in this territory, which have led some researchers to speak of Basque society as a "movement society" (e.g. Barcena and Ajangiz 2011; Casquete 2001), especially in Hegoalde (see footnote 6). It has long been noted that rates of protest activity and non-institutional political participation in Basque territories are well above those of Spain (Torcal et al. 2006) and other areas of the Western world (Casquete 2006). Such high levels of mobilization provide a vast pool of protest events for analysis, thus allowing a more fine-grained examination of the changing modularity of a multiplicity of protest tactics. Secondly, previous research has pointed out that, from an aggregative point of view, the protest forms constituting the Basque repertoire are numerous and their relative incidence has changed quite dramatically over the years (Díez Medrano 1995; Ibarra and de la Peña 2004; Letamendia, A. 2015; Letamendia, F. 2000; Tejerina 2001; Zubiaga and Azkune 2018). In terms of quantitative incidence, confrontational and violent political actions were numerous during the late 20th century, while during the first decades of the 21st century a larger share of events were based on symbolic and non-violent forms of protests. The

${ }^{6}$ Throughout this article, we refer to the "Basque Country" in its most extensive definition as a literal English translation of the Basque term Euskal Herria, a cultural area comprising seven historical territories or provinces, three in the Southwestern corner of France (Northern Basque Country or Iparralde), and four in Northern Spain (Southern Basque Country or Hegoalde). This geographical delimitation is based upon the observation that the seven territories considered, despite belonging to separate politico-institutional systems (Ibarra \& Ahedo 2004), make up a common -even if highly heterogeneous- socio-political space in many regards. In spite of multilingualism and the deep-rooted local idiosyncrasies of each territory, these seven culturally Basque territories considered share very often the same socio-political dynamics, campaigns and actors, especially when focusing on contentious politics (e.g. Letamendia, F. 2006). For more details, see: Letamendia, A. (2015: 16) 
aforementioned network approach to modularity proposed above permits to examine to what extent the observed temporal variations in the incidence of different protest forms correspond to deeper changes in their relative modularity within the Basque repertoire of contention, rather than being a mere byproduct of the changing mobilization capabilities and resources of some collective actors specialized in concrete protest forms.

To examine temporal variations in terms of modularity we carry out a secondary analysis of a protest event dataset collected by the second author (see Letamendia, A. 2015, 2018, 2019). The dataset contains information on 4,832 protest events occurred in the Basque Country during four year-long windows: $1980,1995,2010$, and $2014 .^{7}$ These four yearly snapshots allow to contrast the most salient features of contention at very distinct historical periods, from the highly turbulent first post-Franco years to the relatively less conflictive political scenario of the mid-2010s. The construction of this dataset resulted from the application of the well-known methodology of protest event analysis (PEA), ${ }^{8}$ using in this case the Egin/Gara newspapers as sources. ${ }^{9}$ The selection of Egin/ Gara as data sources responded to the special attention these dailies have paid to non-institutional politics and social movements, reporting a much higher number of protest events than other local newspapers. Additionally, it is the only media outlet that consistently covers the entirety of Euskal Herria. For all these reasons, and in spite of the ideological proximity of Egin/Gara with left-wing Basque nationalism, this is still the best possible choice for a single newspaper source when conducting protest event analysis in the Basque context (see Barcena et al. 2003). Moreover, the biases that this partisanship might introduce are less worrying for the assessment of "hard news" (Tuchman 1973), that is, events' factual aspects, which tend to be consistently reported (Danzger 1975; Earl et al. 2004; McPhail \& Schweingruber 1999).

The main unit of analysis, the protest event, is defined as a public gathering in which individuals collectively make a claim against or in support of a target, whenever claim-making occurs outside of prescribed institutional and media channels. ${ }^{10}$ For each reported protest event, two main types of information were

${ }^{7}$ Given the time-consuming nature of PEA and the limitation of time and resources that any kind of research project faces, it is a conventional practice in PEA studies to apply a temporal sampling of the period under study (e.g. Ciordia 2021; Everett 1992; Kriesi et al. 1995; Tilly 1995). This is particularly common when dealing with decades-long long historical periods and undigitalized sources, as in this case. For a justification of the specific years selected please see: Letamendia, A. (2015: 57; 2018: 9; 2019: 5-6).

${ }^{8}$ Among the multiple essays that provide an overview of this method of data collection and review well-known investigations that have resorted to it, interest readers may refer to three in particular: Hutter (2014); Koopmans \& Rucht (2002); and Rucht \& Ohlemacher (1992).

9 Two different -though closely related- newspapers had to be used due to the preventive closure of Egin in 1998 by order of the Spanish Audiencia Nacional, after which the newspaper Gara was founded in 1999, occupying the same position as Egin within the local media landscape.

${ }^{10}$ This definition of the unit of analysis was inspired by several previous PEA studies (for a short review see Hutter 2014: 342-8), being particularly similar to the definitions provided by Soule and Davenport (2009: 8). Therefore, this dataset concentrates on extra-institutional protests 
coded: (a) the chief protest form being deployed at the event, and (b) the type of actors promoting it, classified according to the sector or "social movement industry" (SMI) (McCarthy \& Zald 1977) to which the organizers belonged. The coding of protest forms and actors was conducted in an open manner, generating new categories and recoding old ones when necessary. In the end, 10 basic and relatively broad modes or tactics of protesting and 18 types of collective actors were distinguished. ${ }^{11}$ Table 5 presents all 10 tactics analyzed, ordered according to their overall incidence across the four years. Tactics that were more commonly used appear and those that were observed less frequently figure at the bottom. For each year, we report their relative frequency, that is, the proportion of all events in which a given protest form was employed, as well as their relative yearly rank.

(independently of whether these are demonstrative, confrontational or even violent), leaving aside procedural or appellative actions of discontent (e.g. press conferences, signature petitions, lobbying, judicial actions, etc) as well as 'civic' events (Sampson et al. 2005: 684-6) that usually adopt community-oriented forms (e.g. festivals, cleanups, charity or sport events, etc).

${ }^{11}$ A description of each category of protest forms and collective actors is provided in the Appendix. 


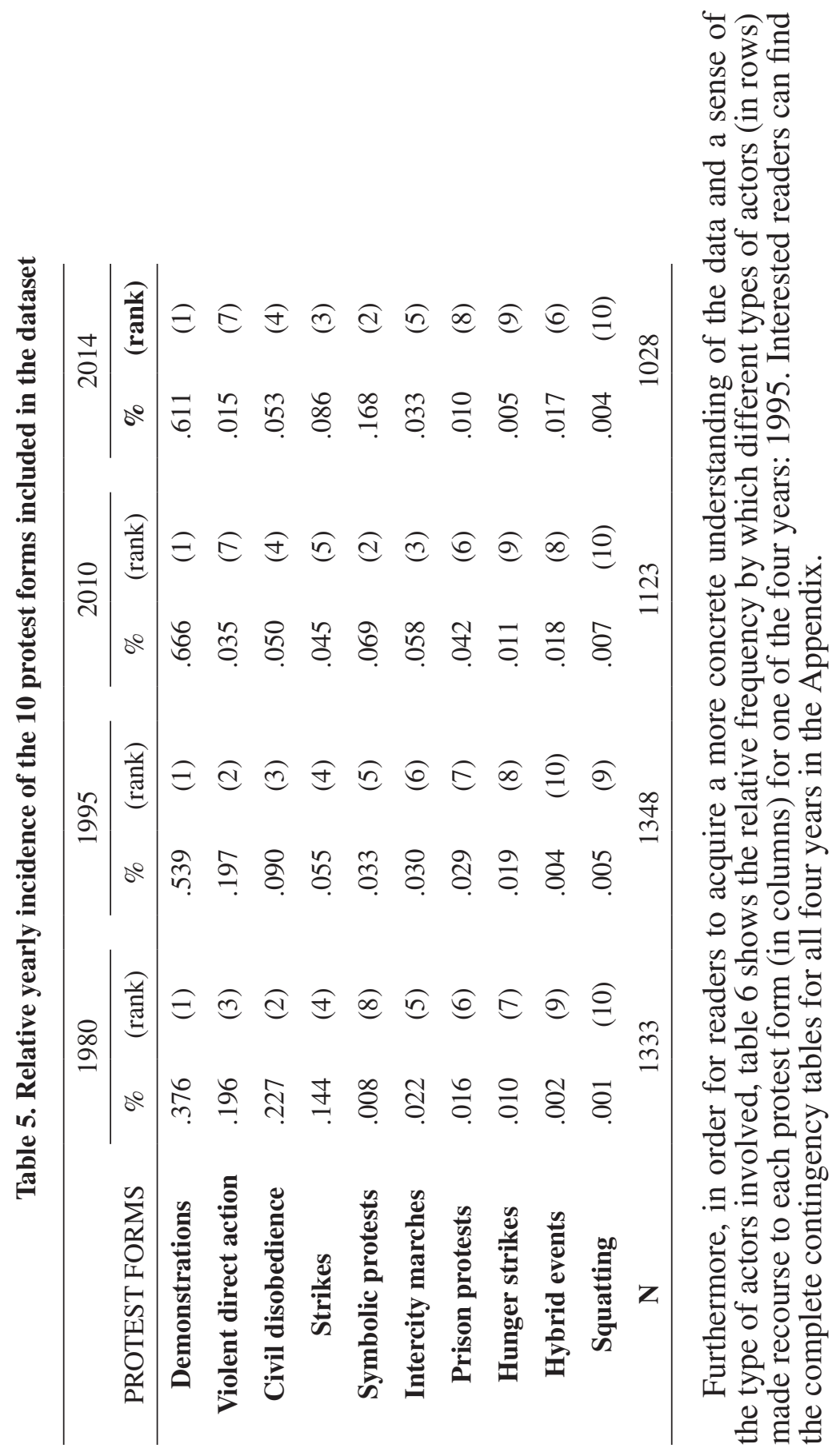




\begin{tabular}{|c|c|c|c|c|c|c|c|c|c|c|c|c|c|c|c|c|c|c|c|}
\hline & 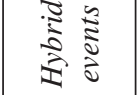 & & & $\bar{\sigma}$ & & & & & & $\tilde{8}$ & & & & & & & ฮิ & & \\
\hline & 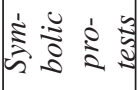 & $\stackrel{0}{0}$ & $\frac{0}{0}$ & $\stackrel{g}{\varrho}$ & है & & I & & ธิ & $\stackrel{m}{\longrightarrow}$ & & $\begin{array}{l}\stackrel{\circ}{n} \\
\text { ก. }\end{array}$ & $\stackrel{m}{0}$ & & & & ฮิ & $\hat{8}$ & \\
\hline & 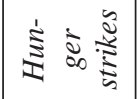 & $\frac{\infty}{0}$ & ฮิ & & & & & शे & & $\overline{8}$ & & & & §્ণ & & & ฮิ & $\stackrel{\infty}{0}$ & \\
\hline 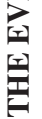 & 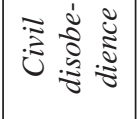 & $\begin{array}{l}0 \\
2 \\
0\end{array}$ & $\stackrel{ \pm}{0}$ & ণ़ & & $\stackrel{m}{m}$ & กิ & शे & $\overline{0}$ & : & & \begin{tabular}{l}
$\stackrel{0}{n}$ \\
\multirow{n}{*}{}
\end{tabular} & & & & & 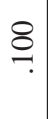 & छे. & \\
\hline 育 & 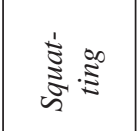 & & & & & & & & & & & & $\begin{array}{l}m \\
\infty \\
n\end{array}$ & & & & & & \\
\hline 产 & 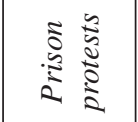 & ? & & & & & $\frac{N}{0}$ & & $\frac{\Delta}{\stackrel{\Delta}{~}}$ & & & & & & & & & & \\
\hline 동 & 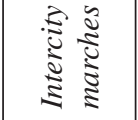 & 气̂. & 옹 & 号 & & & ฮิ & ปั & & & & & & & & \begin{tabular}{l}
8 \\
\hdashline \\
$n$
\end{tabular} & & $\stackrel{\infty}{\sigma}$ & \\
\hline 空 & 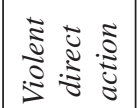 & 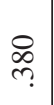 & ? & $\frac{0}{0}$ & bे & & $\frac{t}{0}$ & & & & $\stackrel{g}{ \pm}$ & & & 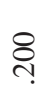 & & & $\stackrel{ \pm}{0}$ & & - \\
\hline & 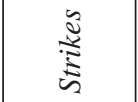 & 8 & $\stackrel{\overbrace{}}{\hat{\imath}}$ & & & & & & & & & & & & & & $\stackrel{0}{\infty}$ & $\frac{\infty}{0}$ & \\
\hline & 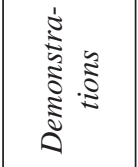 & $\stackrel{n}{r}$ & 尔 & 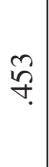 & ڤิ & $\hat{8}$ & $\bar{n}$ & $\underset{\infty}{\infty}$ & f & กิ & $\hat{n}$ & $\begin{array}{l}8 \\
!\end{array}$ & $\stackrel{m}{m}$ & \&్ర & - & \begin{tabular}{l}
8 \\
\hdashline \\
$n$
\end{tabular} & $\underset{\sigma}{\nabla}$ & $\widehat{\widehat{a}}$ & \\
\hline & 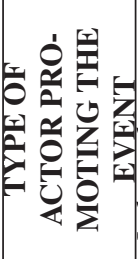 & 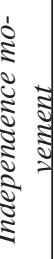 & $\begin{array}{l}\frac{a}{2} \\
\frac{2}{2} \\
\frac{1}{2}\end{array}$ & 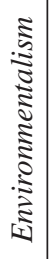 & 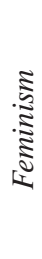 & 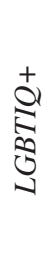 & 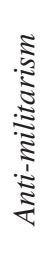 & 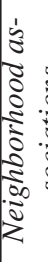 & 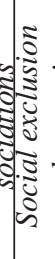 & 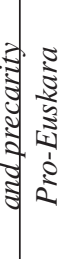 & 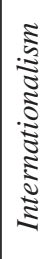 & 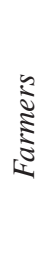 & 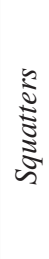 & 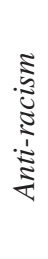 & 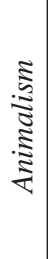 & 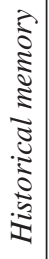 & 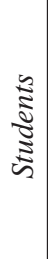 & 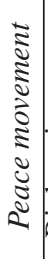 & 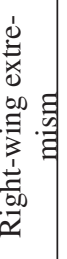 \\
\hline
\end{tabular}




\section{ANALYSES AND RESULTS}

In this section we present the main findings derived from our analyses of the actor transferability of ten different protest forms in the Basque Country over the last four decades. Three complementary types of output will be examined. We will start with a visual inspection of bipartite networks between protest forms and types of actors, moving later to a more detailed examination of our quantitative measure of transferability as weighted degree centrality, and concluding with a more detailed bidimensional analysis of breadth and depth.

\section{Network graphs}

Figure 3 provides a graphic representation of our data, showing one bipartite network graph for each year of observation. Black nodes represent protest forms (our object of analysis), while white nodes represent the different types of actors involved in protest events. Similarly to the network presented in figure 2, node sizes and edge widths are scaled according to total incidence (number of events) and tie strength (usage proportion), respectively. In order to facilitate the interpretation, only ties with a strength greater than .05 are displayed.

All network graphs show a clear center-periphery structure, with most ties centralized on a very limited set of protest forms, which reveals a semi-rigid or "strong" repertoire (Tilly 2006; Wada 2016). Unsurprisingly, conventional demonstrations stand out as the preferential tactic within the Basque repertoire, not as a consequence of it being the most frequently deployed tactic (being the largest node), but rather because it also appears as the best connected node, being used rather intensely by almost every type of actor. Besides this predictable finding, it is interesting to focus on other protest forms that came to occupy relatively central positions within the network at different years. For instance, civil disobedience used to hold a very central position in 1980, gradually moving to the periphery in subsequent observations. On the contrary, symbolic protests progressively moved from the periphery of the network in 1980 (when only environmentalists resorted to this type of protests in at least $5 \%$ of their events) to the center. Indeed, it is interesting to point out the very similar structural position of civil disobedience in 1980 and symbolic protests in 2014 as the second most modular tactic after conventional demonstrations. Furthermore, the very similar structural configuration of the 1980 and 2014 networks could be interpreted as the result of the crystallization of two distinct strong repertoires, with observations from 1995 and 2010 capturing the transition phase between the two. In both points of equilibrium, tactical choice seemed to be quite constrained to two main options: on the one hand, a highly conventional protest form such as orderly demonstrations and rallies, and, on the other hand, a more confrontational alternative. In both years, whenever collective actors decided to resort to more disruptive and non-routine ways of protesting, they tended to favor one specific form of confrontation that was widely diffused and with which they already were familiar. While in the early 80s this preferred form of disruptive confrontation was physical by nature (as civil disobedience, in spite of its non-violent nature, 
entails the direct exposure of activists' bodies), by the 2010s the nature of confrontation had become more symbolic and aesthetic.

Figure 3. Bipartite graphs of protest forms and actor types

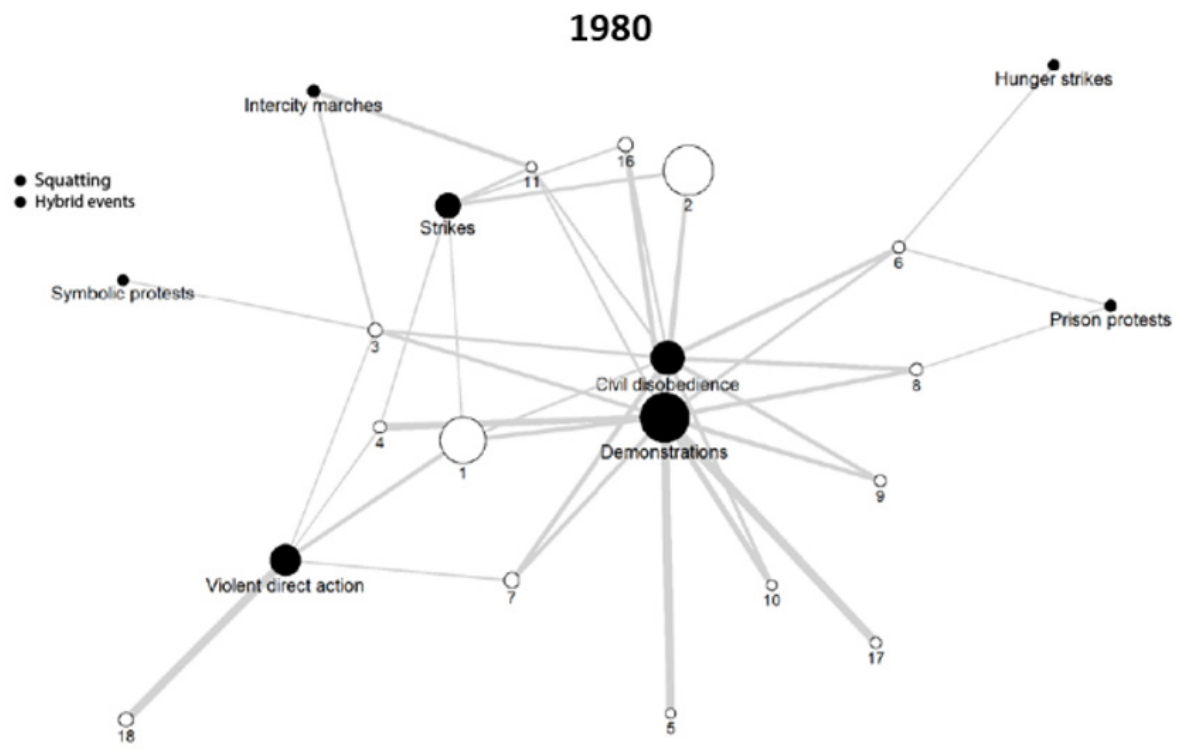



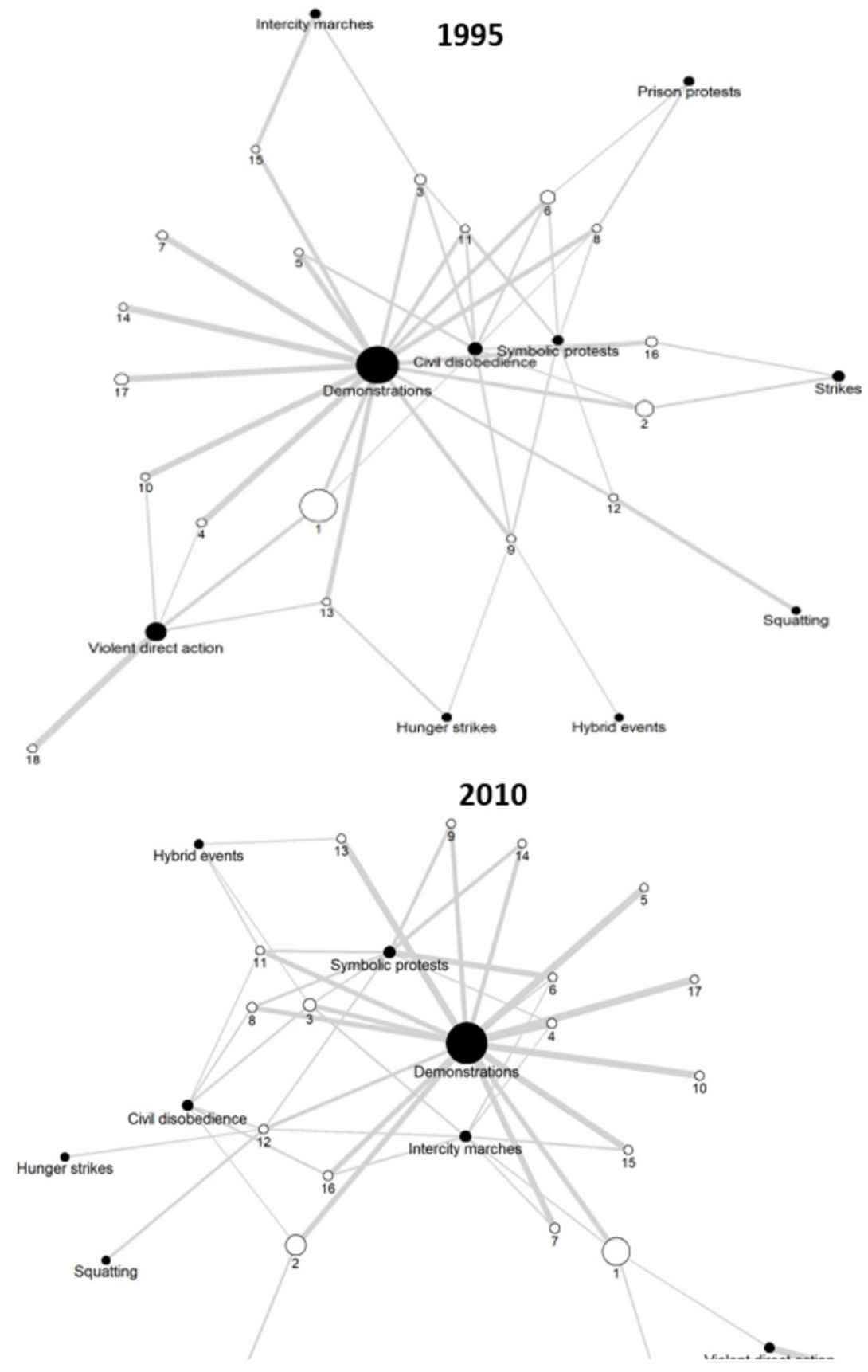

EMPIRIA. Revista de Metodología de Ciencias Sociales. N. ${ }^{\circ} 52$ septiembre-diciembre, 2021, pp. 53-95. ISSN: 1139-5737, DOI/ empiria.52.2021.31365 


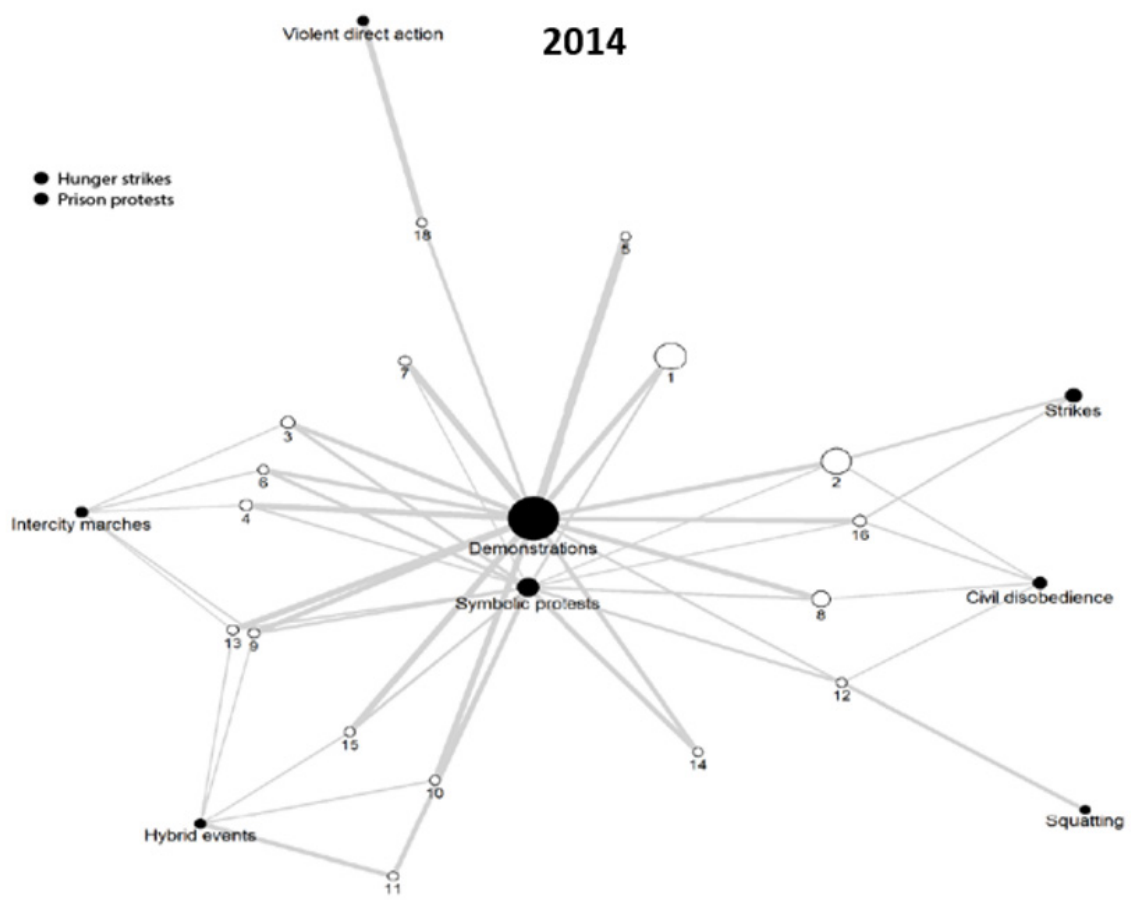

Legend: Network layout drawn according to the Fruchterman-Reingold algorithm.

Key to actors' labels: (1) independence movement, (2) workers, (3) environmentalists, (4) feminists, (5) LGBTIQ+, (6) anti-militarism, (7) neighborhood associationism, (8) social exclusion and precarity, (9) pro-Euskara, (10) internationalism, (11) farmers, (12) squatters, (13) anti-racism, (14) animal rights, (15) historical memory, (16) students, (17) peace movement, (18) right-wing extremism.

It should also be noted how two very recurring protest forms such as violent direct action and strikes (which are, respectively, the second and fourth most frequent tactics overall, taking all years into account; see table 5) were not as central as it could be expected from their aggregate incidence. This is so because only a few actors turned to these tactics in their events, particularly towards the end of the period of analysis, becoming highly particularized. Even though other actors occasionally resorted to these forms, most events in which violent direct action was employed were carried out by actors associated with the proindependence movement or with right-wing extremism, while most strikes were promoted, unsurprisingly, by the labor movement. 


\section{Transferability scores}

In addition to the direct visual inspection of network graphs, a more detailed presentation of the results of our analysis is provided in table 7, which ranks all 10 surveyed forms according to actor transferability, with exact scores between brackets.

Table 7. Modularity of protest forms over time

\begin{tabular}{|c|c|c|c|c|}
\hline Rank & 1980 & 1995 & 2010 & 2014 \\
\hline 1 & $\begin{array}{c}\text { Demonstrations } \\
(.651)\end{array}$ & $\begin{array}{c}\text { Demonstrations } \\
(.747)\end{array}$ & $\begin{array}{c}\text { Demonstrations } \\
(.774)\end{array}$ & $\begin{array}{c}\text { Demonstrations } \\
(.726)\end{array}$ \\
\hline 2 & $\begin{array}{l}\text { Civil disobe- } \\
\text { dience } \\
\text { (.410) }\end{array}$ & $\begin{array}{l}\text { Civil disobe- } \\
\text { dience } \\
(.221)\end{array}$ & $\begin{array}{c}\text { Symbolic pro- } \\
\text { tests } \\
(.266)\end{array}$ & $\begin{array}{c}\text { Symbolic pro- } \\
\text { tests } \\
(.419)\end{array}$ \\
\hline 3 & $\begin{array}{l}\text { Violent direct } \\
\text { action } \\
(.220)\end{array}$ & $\begin{array}{l}\text { Violent direct } \\
\text { action } \\
(.182)\end{array}$ & $\begin{array}{c}\text { Intercity mar- } \\
\text { ches } \\
\end{array}$ & $\begin{array}{l}\text { Hybrid events } \\
(.138)\end{array}$ \\
\hline 4 & $\begin{array}{l}\text { Strikes } \\
(.175)\end{array}$ & $\begin{array}{c}\text { Symbolic pro- } \\
\text { tests } \\
(.154)\end{array}$ & $\begin{array}{l}\text { Civil disobe- } \\
\text { dience } \\
(.125)\end{array}$ & $\begin{array}{l}\text { Intercity mar- } \\
\text { ches } \\
(.126)\end{array}$ \\
\hline 5 & $\begin{array}{l}\text { Intercity mar- } \\
\text { ches } \\
(.116)\end{array}$ & $\begin{array}{c}\text { Intercity mar- } \\
\text { ches } \\
(.107)\end{array}$ & $\begin{array}{l}\text { Violent direct } \\
\text { action } \\
(.087)\end{array}$ & $\begin{array}{l}\text { Civil disobe- } \\
\text { dience } \\
(.105)\end{array}$ \\
\hline 6 & $\begin{array}{c}\text { Symbolic pro- } \\
\text { tests } \\
(.077)\end{array}$ & $\begin{array}{c}\text { Hunger strikes } \\
(.085)\end{array}$ & $\begin{array}{c}\text { Hybrid events } \\
(.081)\end{array}$ & $\begin{array}{l}\text { Violent direct } \\
\text { action } \\
(.085)\end{array}$ \\
\hline 7 & $\begin{array}{l}\text { Hunger strikes } \\
\text { (.064) }\end{array}$ & $\begin{array}{c}\text { Strikes } \\
(.065)\end{array}$ & $\begin{array}{l}\text { Squatting } \\
\quad(.036)\end{array}$ & $\begin{array}{l}\text { Strikes } \\
(.063)\end{array}$ \\
\hline 8 & $\begin{array}{c}\text { Prison protests } \\
(.055)\end{array}$ & $\begin{array}{l}\text { Prison protests } \\
\text { (.052) }\end{array}$ & $\begin{array}{l}\text { Strikes } \\
(.033)\end{array}$ & $\begin{array}{l}\text { Squatting } \\
\quad(.037)\end{array}$ \\
\hline 9 & $\begin{array}{l}\text { Hybrid events } \\
\quad(.025)\end{array}$ & $\begin{array}{l}\text { Squatting } \\
\quad(.042)\end{array}$ & $\begin{array}{l}\text { Hunger strikes } \\
\text { (.028) }\end{array}$ & $\begin{array}{c}\text { Hunger strikes } \\
(.018)\end{array}$ \\
\hline 10 & $\begin{array}{l}\text { Squatting } \\
(.014)\end{array}$ & $\begin{array}{c}\text { Hybrid events } \\
(.034)\end{array}$ & $\begin{array}{c}\text { Prison protests } \\
(.018)\end{array}$ & $\begin{array}{c}\text { Prison protests } \\
(.010)\end{array}$ \\
\hline
\end{tabular}

Besides providing a more precise quantitative corroboration of the most salient features emerging from the visual inspection of network graphs, a comparison of the transferability scores reported in table 7 with the aggregate relative frequency of each tactic reported in table 5 show that modularity and incidence are largely complementary, rather than opposed, analytical dimensions. As a matter of fact, yearly transferability scores strongly correlate in this case with incidence percentages (Pearson's $r=.95$ ). Nonetheless, modularity analyses are still worth pursuing in order not to overestimate the relevance of those tactics preferred by actors with higher mobilization capacities, nor to underestimate 
the acceptability and familiarity acquired by some forms of protests that might nonetheless remain low in terms of absolute number of events. Prison protests and strikes are paramount examples of tactics that were less relevant within the Basque repertoire of contention once their modularity was assessed than what was initially suggested by simple event counts. Another telling example of dissonance between incidence and modularity is given by violent direct action in 1995, which was the second most frequent type of contentious action but figured third in terms of actor transferability, being less central within the Basque repertoire than civil disobedience despite the former being used in twice as many events. On the other side, by 2014 hybrid events became the third most transferable form of protest, despite having observed just 17 such gatherings, less than $2 \%$ of total events. In spite of its low numbers, as many as nine different types of collective actors experimented with this form of "blended social action" in at least one of their gatherings that year, revealing the rising legitimacy of this flexible combination of explicit claims asking for specific change with civic or community-based activities, often with a marked festive character (Sampson et al. 2005: 680-1).

At this point, readers might be asking themselves: but how do these results compare to the scores that would be obtained applying Wada's measures? In order to answer this question, we also analyzed the annual contingency tables that serve us as network matrices following Wada's operationalization. Even though full results are not reported here, these are nonetheless available upon request. As it happened for the hypothetical example reviewed above, the results obtained through either operationalization procedures were extremely similar, both with respect to exact scores $(r=.95)$ and to their relative ranking $(r=.86)$. Nevertheless, one important divergence between scores of weighted degree centrality and Wada's measures should be noted: the overestimation by the latter of the transferability of 'strongly particular' tactics, those used by very few actors, though quite frequently (see figure 1). Actor transferability scores of squatting and violent direct action were systematically inflated when applying Wada's operationalization in comparison with our measure. For instance, had we followed Wada's operationalization, squatting would have appeared as the third most modular protest form in 1995 despite having been observed in only seven occasions during the entire year, always being carried out by actors associated with the squatters' movement. Another telling example of this bias is illustrated by the divergent results obtained by violent direct action in 2010, which were the second most modular form within the Basque repertoire at the time according to Wada's measure. These results contrast sharply with our measures (see table 7), as well as with any intuitive interpretation of the original data matrices and respective network graphs.

\section{Breaking down transferability into breadth and depth}

Apart from the visual exploration of network graphs and the quantitative evaluation of overall transferability measures, we can also engage in a deeper level of analysis in which breadth and depth scores are computed separately, 
looking at their co-evolution over time. By splitting transferability into its two constituent aspects and plotting the results in a two-dimensional space (figure 4) it is possible to better understand the modularity trajectories of every protest form. As noted by Wada (2012: 560), this kind of analysis allows us to disentangle how tactical diffusion (identified by rightward movements) and usage intensification (upward) specifically combine in making a certain protest form more modular over time, that is, moving closer to the upper-right corner of the graph. In the opposite sense, a protest form's loss of transferability (getting closer to the bottom-left corner) can also be the result of varying combinations of particularization (leftward move) and abandonment (downward move).

Figure 4. Evolution of breadth and depth scores of selected protest forms

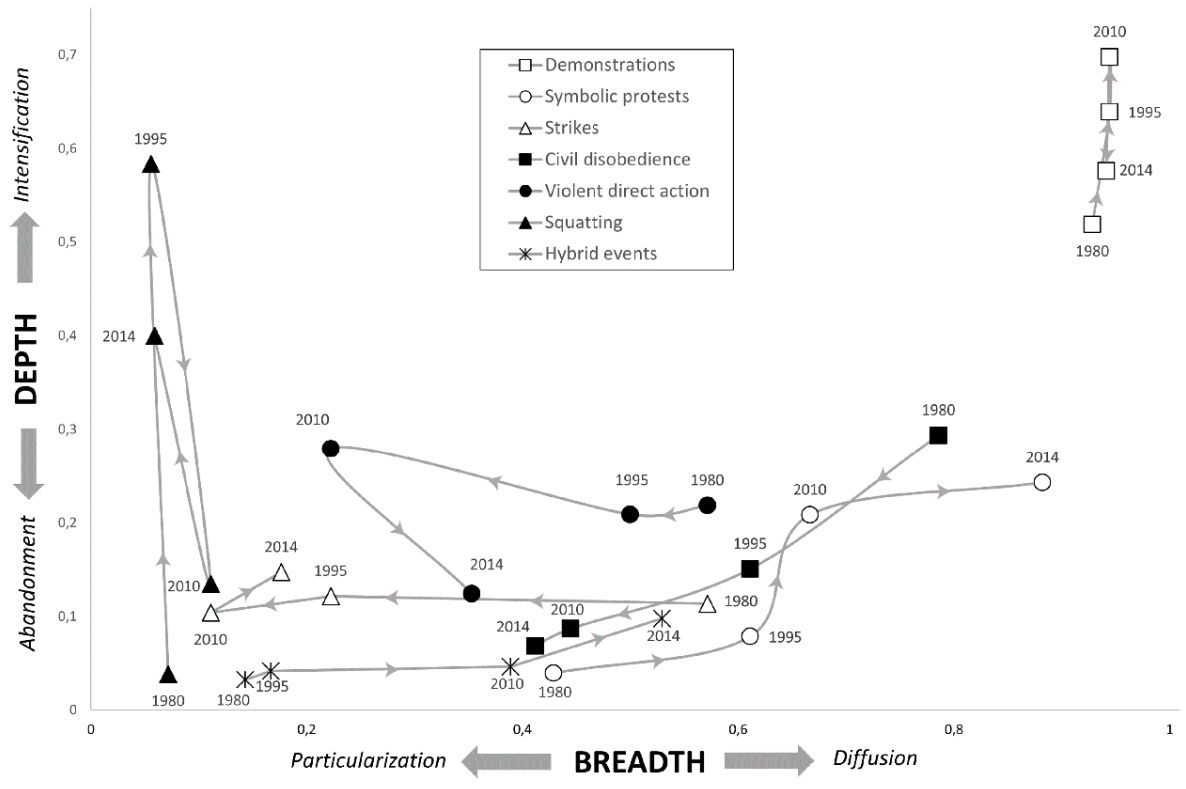

(source: own elaboration, based on Wada 2012: 564)

Once again, demonstrations stand out from the rest of tactics, being situated in the upper-right corner of the graph throughout the entire period analyzed, which makes it a paradigmatic example of a strongly modular protest form. Still, it is interesting to note how collective actors have intensified their use over time, peaking in 2010. The other protest form that follows a distinctive trajectory is squatting, which alternates between a non-modular position and a strongly particular one in 1995 and 2014, when the squatters' movement barely diversified its forms of action. The five remaining tactics are more interesting, 
as they all show notable changes in their modularity, reflected in their relatively long displacements along the chart. On the one hand, strikes, civil disobedience and violent direct action all underwent a significant decrease in modularity. While strikes and violent direct action became less modular mostly due to their particularization (although strikes reversed this tendency after 2010), civil disobedience showed steady and simultaneous processes of particularization and abandonment. On the other hand, symbolic protests and hybrid events became more modular over time. The latter experienced a great deal of diffusion, but the intensity of its usage remained modest. In the case of symbolic protests, its trajectory followed an interesting stair-like shape in which diffusion and intensification alternated, although the former process clearly prevailed during the period examined. In other words, even though the usage of symbolic protests also intensified, its remarkable overall increase in modularity was mainly due to its diffusion among new actors.

\section{DISCUSSION AND CONTRIBUTIONS}

By developing an innovative network-based measure of modularity, this article provides a new methodological tool that, even though it is far from being opposed to Wada's original measure, presents several potential advantages that may facilitate its popularization among researchers interested in repertoires of contention. From a practical point of view, by treating the contingency tables of protest event datasets as two-mode networks we are able to: (i) compute transferability scores in a single step, (ii) operationalize breadth and depth in an extremely intuitive way, and (iii) obtain an easily interpretable graphic representation of the data that can greatly help the analyst in navigating the complexity of large event datasets. Furthermore, in contrast to the implicit assumption made by Wada about the equal relevance of breadth and depth for the assessment of transferability, the possibility to assign different values to the tuning parameter $\mathbb{Q}$ for the calculation of weighted degree centrality makes our measure compatible with different theoretical assumptions on the relative weight of these two constitutive aspects of modularity. We believe all these features might make our proposed operationalization more appealing to researchers interested in obtaining systematic assessments of the varying modularity of forms of contention across contexts and periods. While this endeavor seems merely descriptive at first sight, the ability to generate comparable scores capturing how modular every available tactic within a repertoire is opens fascinating lines of future inquiry regarding both the determinants and the consequences of the ways through which contention specifically occurs (see Wada 2012: 568).

Besides its methodological contributions, our analysis of the changing modularity of several protest forms in the Basque Country has also unveiled some interesting substantive insights that would have hardly been obtained otherwise. While developing a comprehensive explanatory framework of the evolution of the Basque repertoire of contention falls outside the scope of this article, we 
consider it necessary to briefly discuss some of the most salient findings and its connections to both the particular evolution of contentious politics in the territory as well as to global social trends. This way, we show the great potentiality of this type of empirical modularity analyses for the development of more robust historical explanations about the changing features of non-institutional politics.

The most notable shift observed refers to the contrast between the more disruptive and physical nature of non-routine confrontation in the 1980s (civil disobedience and, to a lesser extent, violent direct action) and the more moderate and aesthetic character of the preferred alternative to demonstrations in the 2010s (symbolic protests). On the one hand, the sharp descent of violent direct action's transferability reflects to a large extent the increasing delegitimization of revolutionary violence, while the downfall of civil disobedience as a modular tactic was largely the result of the growing costs that activists faced since the 1990s. From that decade onwards, new means of legal repression implemented by the state under the banner of the fight against terrorism effectively criminalized many non-violent forms of dissent (see Alonso et al. 2014; Casado da Rocha and Pérez 1996; Letamendia, A. 2011). On the other hand, the modularization of symbolic actions of claim-making, such as theatrical performances, seems to be closely associated with the dramatic macrostructural changes in communication technologies and the digitalization of social life (Castells 2009), as well as with the concomitant mediatization and aestheticization of politics (Harvey 1989). These consolidated features of the $21^{\text {st }}$ century's socio-political context are certainly more favorable to symbolic tactics that contain visually striking messages and that are particularly suitable to be recorded and then quickly disseminated over the Internet (Letamendia, A. 2017). Indeed, the particular shape of symbolic protests' rising curve, which increased significantly more in terms of breadth than depth (see figure 4) can be seen as a reinforcing sign of the plausibility of our macrostructural explanation. The processes of digitalization and aestheticization of social and political life gradually created a fertile ground for experimentation with innovative symbolic forms of protests, leading to strong initial diffusion followed by a more modest intensification later on, which is likely to have continued after 2014.

Furthermore, this last observation leads us to formulate a more general proposition regarding the association between modularization trajectories and the power of competing theoretical explanations of how tactics become modular. While concave-up curves marked by initial diffusion and subsequent intensification -similar to the trajectory observed for symbolic protests and hybrid eventsare more compatible with macrostructural causal explanations, concave-down curves characterized by the opposite sequence of initial intensification followed by diffusion -not observed in our data- would be more congruous with explanations based on the "cycle of protest" (McAdam 1995; Tarrow 1995, 1998). The latter contend that a marginal tactic can become modular when initiators of a protest cycle prove the effectiveness of a tactical innovation and are subsequently imitated by others. This tentative proposition, while certainly open 
to future qualifications, points towards the great potential of in-depth empirical assessments of modularity for theoretical validation and refinement.

\section{REFERENCES}

ALONSO, C., BARCENA, I. and GOROSTIDI, I. (2014): "Repression and Criminalization of the Ecologist Movement in the Basque Country: The Case of the High Speed Train Project", Oñati Socio-Legal Series, 4(1), pp. 13-34.

BARCENA, I. and AJANGIZ, R. (2011): "Basque Social Movements", in Basque Political Systems, Reno, NV, University of Nevada Press, pp. 219-34.

BARCENA, I., IBARRA, P., GUARROTXENA, E. and TORRE, J. (2003): “The Basque Country", in Environmental Protest in Western Europe, Oxford, Oxford University Press, pp. 200-215.

BARRAT, A., BARTHÉLEMY, M., PASTOR-SATORRAS, R. and VESPIGNANI, A. (2004): "The Architecture of Complex Weighted Networks", Proceedings of the National Academy of Sciences, 101(11), pp. 3747-52.

BIGGS, M. (2013): "How Repertoires Evolve: The Diffusion of Suicide Protest in the Twentieth Century", Mobilization: An International Quarterly, 18(4), pp. 407-28.

BONACICH, P. (1987): "Power and Centrality: A Family of Measures", American Journal of Sociology, 92(5), pp. 1170-82.

BORGATTI, S. P., EVERETT, M. G. and JOHNSON, J. C. (2013): Analyzing Social Networks, London, SAGE.

CASADO DA ROCHA, A. and J. A. PÉREZ (1996): Itoiz: del Deber de la Desobediencia Civil al Ecosabotaje, Pamplona-Iruña, Pamiela.

CASQUETE, J. (2001): “Accion Colectiva y Sociedad de Movimientos: el Movimiento Antimilitarista Contemporáneo en el País Vasco-Navarro”, Cuadernos Sociológicos Vascos, Vitoria-Gasteiz, Gobierno Vasco.

CASQUETE, J. (2006): "The Power of Demonstrations", Social Movement Studies, 5(1), pp. 45-60.

CASTELLS, M. (2009): The Rise of the Network Society: The Information Age (2nd ed.), Oxford, Wiley.

CIORDIA, A. (2021). Less Divided after ETA? The evolution of ideological cleavages in the Basque environmental field, 2007-2017, Mobilization: An International Quarterly, 26(2), pp. 217-236.

CRUZ, R. (2008): Repertorios: La Política de Enfrentamiento en el Siglo XX, Madrid, CIS.

CRUZ, R. (2015): Protestar en España 1900-2013, Madrid, Alianza.

DANZGER, M. H (1975): "Validating Conflict Data", American Sociological Review, 40(5), pp. 570-84.

DÍEZ MEDRANO, J. (1995): Divided Nations: Class, Politics, and Nationalism in the Basque Country and Catalonia, Ithaca, NY, Cornell University Press.

DOHERTY, B. and G. HAYES (2019): "Tactics and Strategic Action", in The Wiley Blackwell Companion to Social Movements (2nd ed.), Oxford, Blackwell Publishing, pp. 271-88.

EARL, J., MARTIN, A., McCARTHY, J. and SOULE, S. (2004): “The Use of Newspaper Data in the Study of Collective Action", Annual Review of Sociology, 30(1), pp. 65-80. 
EVERETT, K. D. (1992). Professionalization and Protest: Changes in the Social Movement Sector, 1961-1983, Social Forces, 70(4), 957-975.

FREEMAN, L. C. (1978): "Centrality in Social Networks Conceptual Clarification", Social Networks, 1(3), pp. 215-39.

HARVEY, D. (1989): The Condition of Postmodernity: An Enquiry into the Origins of Cultural Change, Oxford, Blackwell.

HUTTER, S. (2014): "Protest Event Analysis and Its Offspring", in Methodological Practices in Social Movement Research, Oxford, Oxford University Press, pp. 335-67.

IBARRA, P., \& AHEDO, I. (2004). The Political Systems of the Basque Country: Is a Non-Polarized Scenario Possible in the Future?, Nationalism and Ethnic Politics, 10(3), 355-386.

IBARRA, P. and DE LA PEÑA, A. (2004): De la confrontación militante a la cooperación pragmática: Nuevas formas de acción colectiva en Euskadi, Madrid, Catarata.

ITÇAINA, X. (2017): "Conclusion: Popular Culture, Folk Traditions and Protest-A Research Agenda", in Protest, Popular Culture and Tradition in Modern and Contemporary Western Europe, London, Palgrave Macmillan UK, pp. 229-48.

KOOPMANS, R., and RUCHT, D. (2002): "Protest Event Analysis", in Methods of Social Movement Research, Minneapolis, MN, University of Minnesota Press, pp. 231-59.

KRIESI, H., KOOPMANS, R., DUYVENDAK, J. W., \& GIUGNI, M. G. (Eds.). (1995), New Social Movements in Western Europe: A Comparative Analysis, London, UCL Press.

LETAMENDIA, A. (2011): "Represión Legal y Vínculos Organizacionales: el caso del Conflicto Vasco", in Recuperando la Radicalidad. Un encuentro en torno al análisis político crítico, Barcelona, Hacer, pp. 149-69.

LETAMENDIA, A. (2015): La Forma Social de la Protesta en Euskal Herria 1980-2013. Doctoral thesis, Leioa, University of the Basque Country (UPV/EHU).

LETAMENDIA, A. (2017): "Towards the Aestheticisation of the Resistances in the Digital Age? A Critical Approach", in Precarity within the Digital Age, Wiesbaden, Springer, pp. 135-49.

LETAMENDIA, A. (2018): “Acciones simbólicas, conflictos materiales: la evolución contemporánea de la Forma Social de la Protesta vasca", Athenea Digital. Revista de pensamiento e investigación social, 18(3), e2052.

LETAMENDIA, A. (2019): "Las transformaciones de la movilización social en Euskal Herria: del posfranquismo a la década de 2010", Anuario de Movimientos Sociales 2018, Fundación Betiko.

LETAMENDIA, F. (2000): Game of Mirrors: Centre-Periphery National Conflicts, London, Ashgate.

LETAMENDIA, F. (2006). Acción colectiva Hegoalde-Iparralde, Madrid, Editorial Fundamentos.

LÓPEZ-MAYA, M. (2002): "Venezuela after the Caracazo: Forms of Protest in a Deinstitutionalized Context", Bulletin of Latin American Research, 21(2), pp. 199-218.

McADAM, D. (1995): “'Initiator' and 'Spin-off' Movements: Diffusion Processes in Protest Cycles", in Repertoires and Cycles of Collective Action, Durham, NC, Duke University Press, pp. 217-40.

McCARTHY, J. and ZALD, M. (1977): "Resource Mobilization and Social Movements: A Partial Theory", American Journal of Sociology, 82(6), pp. 1212-41. 
McPHAIL, C. (2013): "Modular Protest Forms", in The Wiley-Blackwell Encyclopedia of Social and Political Movements, Malden, MA, Wiley-Blackwell, pp. 757-62

McPHAIL, C. and SCHWEINGRUBER, D. (1999): "Unpacking Protest Events: A Description Bias Analysis of Media Records with Systematic Direct Observations of Collective Action - The 1995 March for Life in Washington, D.C.", in Acts of Dissent: New Developments in the Study of Protest, Lanham, MD, Rowman \& Littlefield, pp. 164-95.

MEYER D. and TARROW, S. (1998): “A Movement Society: Contentious Politics for a New Century”, in The Social Movement Society, Lanham, MD, Rowman \& Littlefield, pp. 1-28.

NEWMAN, M. E. J. (2004): “Analysis of Weighted Networks", Physical Review E, 70 (5), ref. 056131.

OPSAHL, T. (2011): "Degree Centrality and Variation in Tie Weights". Available at: https://toreopsahl.com/2011/08/08/degree-centrality-and-variation-in-tie-weights/ (last accessed: 25/05/2021).

OPSAHL, T., AGNEESSENS, F. and SKVORETZ, J. (2010): "Node Centrality in Weighted Networks: Generalizing Degree and Shortest Paths", Social Networks, 32(3), pp. 245-51.

OPSAHL, T., COLIZZA, V., PANZARASA, P. and RAMASCO, J. J. (2008): "Prominence and Control: The Weighted Rich-Club Effect" Physical Review Letters, 101(16), ref. 168702.

RING-RAMIREZ, M., REYNOLDS-STENSON, H. and EARL, J. (2014): “Culturally Constrained Contention: Mapping the Meaning Structure of the Repertoire of Contention", Mobilization: An International Quarterly, 19 (4), pp. 405-19.

RUCHT, D. and OHLEMACHER, T. (1992): "Protest Event Data: Collection, Uses and Perspectives", in Studying Collective Action, London, SAGE Publications, pp. 76106.

SAMPSON, R., McADAM, D., MacINDOE, H. and WEFFER-ELIZONDO, S. (2005): "Civil Society Reconsidered: The Durable Nature and Community Structure of Collective Civic Action", American Journal of Sociology, 111(3), pp. 673-714.

SOULE, S. (2004): "Diffusion Processes within and across Movements", in The Blackwell Companion to Social Movements (1st ed.), Malden, MA, Blackwell Publishing, pp. 294-310.

SOULE, S. and DAVENPORT, C. (2009): "Velvet Glove, Iron Fist, or Even Hand? Protest Policing in the United States, 1960-1990", Mobilization: An International Quarterly, 14(1), pp. 1-22.

TARROW, S. (1993): "Modular Collective Action and the Rise of the Social Movement: Why the French Revolution Was Not Enough", Politics \& Society, 21(1), pp. 69-90.

TARROW, S. (1995): "Cycles of Collective Action: Between Moments of Madness and the Repertoire of Contention", in Repertoires and Cycles of Collective Action, Durham, NC, Duke University Press, pp. 89-116.

TARROW, S. (1998): Power in Movement: Social Movements and Contentious Politics (2nd ed.), Cambridge, Cambridge University Press.

TEJERINA, B. (2001): "Protest Cycle, Political Violence and Social Movements in the Basque Country", Nations and Nationalism, 7(1), pp. 39-57.

TILLY, C. (1979): "Repertoires of Contention in America and Britain, 1750-1820", in The Dynamics of Social Movements, Cambridge, MA, Winthrop, pp. 126-55.

TILLY, C. (1993): “Contentious Repertoires in Great Britain, 1758-1834”, Social Science History, 17(2), pp. 253-80. 
TILLY, C. (1995): Popular Contention in Great Britain, 1758-1834, London, Routledge. TILLY, C. (2006): Regimes and Repertoires, Chicago, University of Chicago Press.

TILLY, C. (2008): Contentious Performances, Cambridge, Cambridge University Press. TORCAL, M., J. R. MONTERO and J. TEORELL (2006): "La Participación Política en España: Modos y Niveles en Perspectiva Comparada", in Ciudadanos, Asociaciones y Participación en España, Madrid, CIS, pp. 47-76.

TUCHMAN, G. (1973): "Making News by Doing Work: Routinizing the Unexpected", American Journal of Sociology, 79(1), pp. 110-31.

WADA, T. (2012): "Modularity and Transferability of Repertoires of Contention", Social Problems, 59(4), pp. 544-71.

WADA, T. (2016): "Rigidity and Flexibility of Repertoires of Contention", Mobilization: An International Quarterly, 21(4), pp. 449-68.

ZUBIAGA, M., and J. AZKUNE. (2018): "Sobre los Límites del Populismo: Gestión de la Excepcionalidad Política y Democratización en España y Euskal Herria”, in Respuestas y Propuestas de Regeneración Frente a la Crisis de la Democracia, Madrid, Tecnos, pp. 51-79. 


\section{APPENDIX - CONTINGENCY TABLES OF PROTEST EVENTS IN THE BASQUE COUNTRY BY TYPE OF ACTORS AND PROTEST FORMS}

\section{GLOSSARY OF TERMS}

\section{Categories of protest forms}

- Demonstrations. Public collective gatherings of people on the streets, including demonstrations, rallies, and intra-city marches.

- $\quad$ Strikes. Collectively agreed stoppage of work.

- Violent direct action. Acts that immediately inflict physical damage on persons and/or objects with the objective of spreading a political message and/or obtaining political gains. In addition, these acts usually result from some form of coordination among several perpetrators. This category comprises a wide range of forms of confrontation and political violence, such as confrontations with the police, barricades, sabotage, and armed actions.

- Intercity marches. Marches carried out over relatively long distances, most often between distant localities. These can be carried out on foot, bicycles, motorcycles, cars, or tractors.

- Prison protests. Public protests by staged by prisoners and/or next to prisons' premises.

- Squatting. Illegal occupation of an abandoned or unoccupied area of land or a building.

- Civil disobedience. Public actions expressing a refusal to comply with certain laws considered unjust and that often seek to cause some form of disruption in a peaceful form. These may include (but are not limited to) sit-ins, chainings, or road blockades.

- Hunger strikes. Prolonged or intermittent (i.e. fasts) refusal to eat as a form of public protest.

- Symbolic protests. Symbolic actions that resort to aesthetic and metaphorical communication strategies to convey and spread political messages. These include a wide range of collective actions such as parodies, dramatizations and performances, human chains, audiovisual and telematic events, human puzzles and mosaics, and other recreational and visual forms of vindication.

- Hybrid events. Events that articulate explicit political demands but that do not use forms of action typical of protests, but rather typical of civic community-oriented events such as exhibitions, film screenings, conferences, and culinary or sports competitions. 


\section{$\underline{\text { Categories of protest actors }}$}

1. Independence movement. Actors primarily engaged in the promotion of Basque national self-determination and independence.

2. Workers. Trade unions and other collective actors promoting workers' rights.

3. Environmentalism. Actors primarily engaged in environmental protection.

4. Feminism. Actors primarily engaged in the defense of women's rights.

5. LGBTIQ+. Actors primarily engaged in the defense of the rights of the LGBTIQ+ community.

6. Anti-militarism. Actors primarily engaged in the fight against armies and war.

7. Neighborhood associations. Citizens' groups (whether formal or informal) constituted around a specific neighborhood or municipality.

8. Social exclusion and precarity. Actors primarily engaged in the fight against social exclusion and precarity of disadvantaged social groups.

9. Pro-Euskara. Actors primarily engaged in the revitalization and promotion of the Basque language (Euskara)

10. Internationalism. Actors primarily engaged in the promotion of greater cooperation and solidarity among popular struggles and revolutions around the world.

11. Farmers. Actors primarily engaged in the defense of the rights and interests of farmers and peasants.

12. Squatters. Actors primarily engaged in the promotion of communal squatting and alternative or counter-cultural forms of living.

13. Anti-racism. Actors primarily engaged in the fight against racial and xenophobic discrimination, including groups in solidarity with migrants and refugees.

14. Animalism. Actors primarily engaged in the defense of animals' rights and/or the fight against speciesism.

15. Historical memory. Actors primarily engaged in the promotion of institutional and societal recognition of past human rights violations, particularly during the Spanish Civil War, Franco's dictatorship and the democratic transition period.

16. Students. Student unions and other collective actors promoting students' and youth rights.

17. Peace movement. Actors primarily engaged in the condemnation of violence related to the Basque violent conflict and/or the promotion of a peaceful resolution of it.

18. Right-wing extremism. Actors holding far right ideological positions primarily engaged in the promotion of Spanish ultranationalist unionism and/or anti-Basque sentiments. 


\begin{tabular}{|c|c|c|c|c|c|c|c|c|c|c|c|c|c|c|c|c|}
\hline 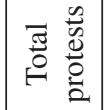 & જิ & \begin{tabular}{l}
$\infty$ \\
\hdashline \\
$n$
\end{tabular} & g̊ & $\stackrel{\sim}{2}$ & $N$ & શे & જิ & లి & $\vec{\sim}$ & 0 & $n$ & ウ & $\stackrel{9}{-}$ & in & $\nabla$ & $\begin{array}{l}m \\
m\end{array}$ \\
\hline 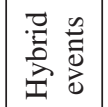 & & & & & & & & & - & & & - & & & & $\mathrm{N}$ \\
\hline 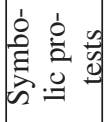 & - & & $n$ & - & & & $N$ & & - & & & - & & & & $\Xi$ \\
\hline 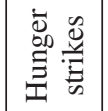 & $\nabla$ & $\nabla$ & - & & & $N$ & - & - & & & & & & & & 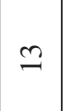 \\
\hline 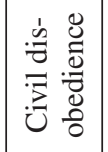 & $n$ & 点 & 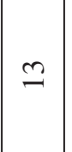 & - & & \pm & ñ & $\underline{2}$ & $\infty$ & $N$ & - & $\simeq$ & & & & $\hat{\overbrace{}}$ \\
\hline $\begin{array}{l}\dot{\vec{E}} \\
\vec{\Xi} \\
\vec{\omega}\end{array}$. & & & & - & & & & & & & & & & & & - \\
\hline 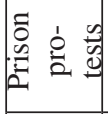 & 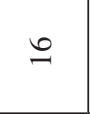 & & & & & $m$ & & $N$ & & & & & & & & $\bar{N}$ \\
\hline 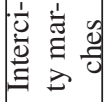 & $=$ & $n$ & $a$ & & & - & - & & & & $N$ & & & & & নे \\
\hline 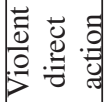 & $\underset{0}{\mathscr{0}}$ & 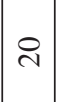 & $\forall$ & 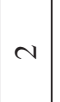 & & & $\infty$ & - & & & & $N$ & & $\stackrel{\circ}{n}$ & & $\vec{\delta}$ \\
\hline 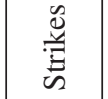 & $\stackrel{\Xi}{\sim}$ & กี & - & $m$ & & & - & & - & & - & $a$ & & & & $\sigma$ \\
\hline ڤે & $\infty$ & $\stackrel{m}{I}$ & $\stackrel{0}{ }$ & $\infty$ & $N$ & $a$ & $\stackrel{ \pm}{\sim}$ & $\underline{\imath}$ & $\varrho$ & $\nabla$ & - & $\vec{n}$ & 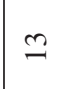 & & $\nabla$ & 8 \\
\hline & 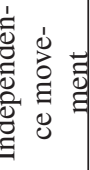 & $\frac{n}{\dot{0}}$ & 造 & 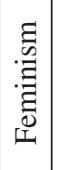 & 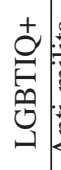 & 离 & 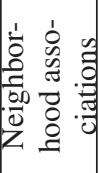 & 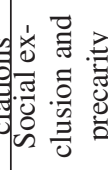 & 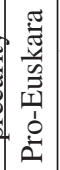 & 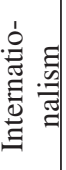 & 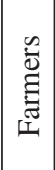 & 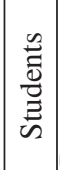 & 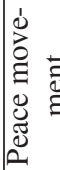 & 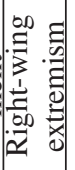 & \begin{tabular}{|l|}
$*$ \\
$*$ \\
$\tilde{\omega}$ \\
$\tilde{\Xi}$ \\
0 \\
\end{tabular} & 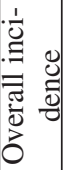 \\
\hline
\end{tabular}


A. CIORDIA Y A. LETAMENDIA I USING SOCIAL NETWORK ANALYSIS TO STUDY ... 89

\begin{tabular}{|c|c|c|c|c|c|c|c|c|c|c|c|c|c|c|}
\hline 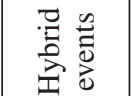 & & & & & & & & & 車 & & & $\stackrel{\infty}{\sigma}$ & & \\
\hline 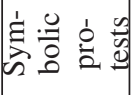 & ఠి & & $\stackrel{\Im}{\varrho}$ & $\stackrel{\infty}{\widetilde{c}}$ & & & ฮิ & & $\begin{array}{l}\infty \\
0 \\
\end{array}$ & & & $\stackrel{\infty}{0}$ & & \\
\hline 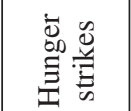 & छे & $\stackrel{\infty}{8}$ & ڤ్ & & & के & $\frac{ \pm}{\sigma}$ & ڤె. & & & & & & \\
\hline 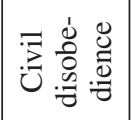 & $\stackrel{n}{=}$ & ڤి & ֶి & $\underset{\wp}{\infty}$ & & $\stackrel{\infty}{+}$ & ț. & $\stackrel{m}{\stackrel{f}{q}}$ & $\begin{array}{l}\vec{\infty} \\
?\end{array}$ & $\stackrel{m}{m}$ & ¿্ণ & $\stackrel{\nabla}{\stackrel{\Delta}{*}}$ & & \\
\hline 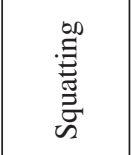 & & & & $\stackrel{\infty}{ల}$ & & & & & & & & & & \\
\hline 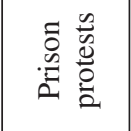 & है & & & & & 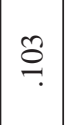 & & $\hat{8}$ & & & & & & \\
\hline 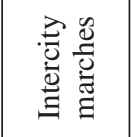 & ปั & $\stackrel{0}{0}$ & $\stackrel{+}{\infty}$ & & & ڤે & $\frac{\Delta}{0}$ & & & & \& & & & \\
\hline 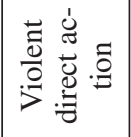 & $\underset{?}{\stackrel{0}{0}}$ & હે & $\stackrel{\substack{0 \\
0}}{0}$ & 今ે & & & $\stackrel{0}{=}$ & है? & & & & గొ & & - \\
\hline 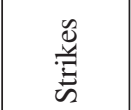 & ถู & ঐे & 잉 & $\cong$ & & & $\frac{\Delta}{0}$ & & 我 & & 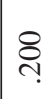 & $\overrightarrow{0}$ & & \\
\hline ఏ̊ & $\hat{n}$ & 守 & तิ & જ̆ & - & $\stackrel{\circ}{m}$ & $\stackrel{\infty}{\stackrel{+}{?}}$ & $\tilde{m}$ & $\begin{array}{l}0 \\
+ \\
f\end{array}$ & $\widehat{\delta}$ & $\underset{\sim}{\stackrel{్}{~}}$ & 蓉 & - & \\
\hline & 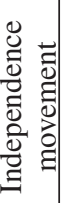 & 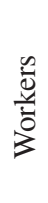 & 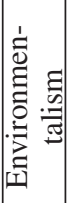 & $\begin{array}{l}\text { E } \\
. \\
\text { 范 } \\
0 \\
\text { DI }\end{array}$ & 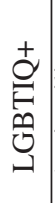 & 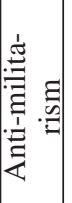 & 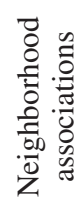 & 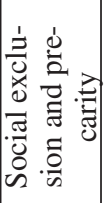 & 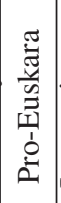 & 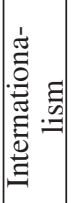 & 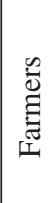 & 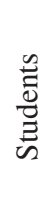 & 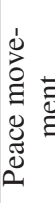 & 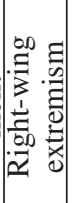 \\
\hline
\end{tabular}




\begin{tabular}{|c|c|c|c|c|c|c|c|c|c|c|c|c|c|c|c|c|c|c|c|c|}
\hline 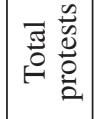 & $\stackrel{0}{0}$ & 亏્へ & J & શิ & $m$ & ફે & $\exists$ & \pm & $\cong$ & $r$ & $\nabla$ & $\simeq$ & in & $m$ & $\sim$ & 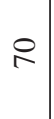 & $\stackrel{8}{0}$ & 0 & $\nabla$ & 文 \\
\hline 홀 & & & $N$ & & & & & & - & & & & & & & $N$ & & & & in \\
\hline 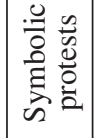 & 으 & $N$ & $r$ & - & & I & & - & $N$ & & -1 & - & & & & $N$ & - & & & $\stackrel{n}{f}$ \\
\hline 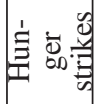 & $=$ & in & & & & & $N$ & & - & & & & - & & & $N$ & $N$ & & & 志 \\
\hline 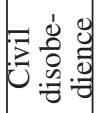 & के & $\vec{\sim}$ & $\simeq$ & & - & $\tilde{m}$ & $N$ & - & $m$ & & - & & & & & $r$ & - & & & $\bar{\beth}$ \\
\hline 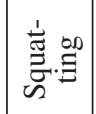 & & & & & & & & & & & & $r$ & & & & & & & & $r$ \\
\hline 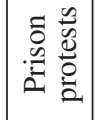 & i & & & & & 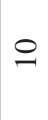 & & $m$ & & & & & & & & & & & & ले \\
\hline 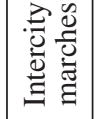 & $\because n$ & $\infty$ & & & & $\forall$ & - & & & & & & & & - & & $N$ & & & F \\
\hline $\begin{array}{l}\overrightarrow{\vec{z}} \\
\frac{0}{0} \\
0\end{array}$ & $\widetilde{\sim}$ & $a$ & - & $N$ & & $\alpha$ & & & & - & & & - & & & - & & 0 & & no \\
\hline 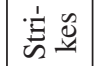 & $m$ & 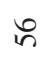 & & & & & & & & & & & & & & 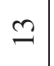 & $N$ & & & 寺 \\
\hline ڤُ & $\frac{2}{2}$ & \& & $\stackrel{\curvearrowright}{ }$ & i & $\mathrm{N}$ & $\bar{\nabla}$ & r & $a$ & $\infty$ & 0 & $N$ & $\nabla$ & $m$ & $m$ & - & $\stackrel{m}{f}$ & $\overline{0}$ & & $\nabla$ & $\widehat{N}$ \\
\hline & 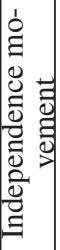 & 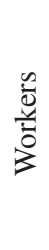 & 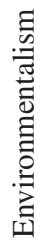 & 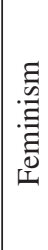 & $\begin{array}{l} \pm \\
0 \\
0 \\
0 \\
0 \\
0\end{array}$ & 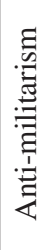 & 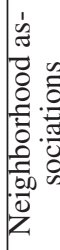 & 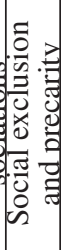 & 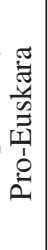 & 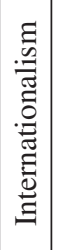 & 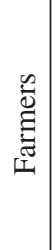 & 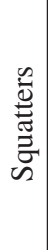 & 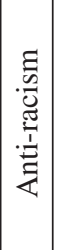 & 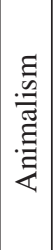 & 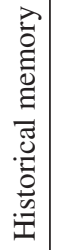 & 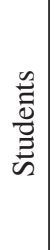 & 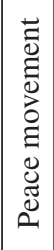 & 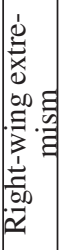 & $\frac{*}{0}$ & 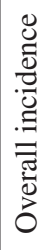 \\
\hline
\end{tabular}


A. CIORDIA Y A. LETAMENDIA USING SOCIAL NETWORK ANALYSIS TO STUDY ... 91

\begin{tabular}{|c|c|c|c|c|c|c|c|c|c|c|c|c|c|c|c|c|c|c|}
\hline 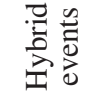 & & & $\overline{\tilde{o}}$ & & & & & & ㅇ․ & & & & & & & ठิे & & \\
\hline 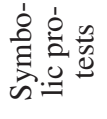 & $\begin{array}{l}0 \\
0 \\
0\end{array}$ & $\frac{0}{0}$ & $\stackrel{8}{0}$ & के & & $\underset{\nearrow}{\Xi}$ & & $\overline{5}$ & $\tilde{m}$ & & i̊ & $\tilde{\infty}$ & & & & ठิ̀ & ठे & \\
\hline 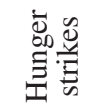 & $\frac{\infty}{0}$ & ฮิ & & & & & جे & & $\hat{0}$ & & & & ஓ્ণ & & & ठิ. & $\stackrel{\infty}{0}$ & \\
\hline 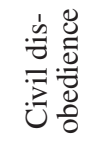 & $\begin{array}{l}0 \\
2 \\
0\end{array}$ & 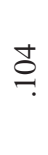 & $\stackrel{\oplus}{\oplus}$ & & $\stackrel{m}{m}$ & ฟิ & جे & $\overline{5}$ & ્ְণ & & $\stackrel{\circ}{n}$ & & & & & 8 & \&े & \\
\hline 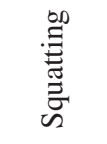 & & & & & & & & & & & & $\begin{array}{l}n \\
\infty \\
n\end{array}$ & & & & & & \\
\hline 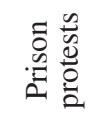 & $\stackrel{m}{0}$ & & & & & $\widehat{N}$ & & $\stackrel{\Delta}{\unlhd}$ & & & & & & & & & & \\
\hline 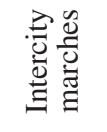 & ฮิ & 웅 & $\stackrel{0}{n}$ & & & ठิ & ণ্ড & & & & & & & & 8 & & $\stackrel{\infty}{\sigma}$ & \\
\hline 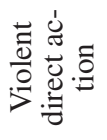 & $\begin{array}{l}\infty \\
\infty \\
\text { ? }\end{array}$ & $\frac{n}{6}$ & $\begin{array}{l}0 \\
0 \\
0\end{array}$ & बे. & & $\stackrel{ \pm}{0}$ & & & & $\stackrel{\mathscr{I}}{ \pm}$ & & & ¿্ণ & & & $\stackrel{+}{0}$ & & - \\
\hline$\stackrel{1}{\Xi} \stackrel{\mathscr{a}}{\mathscr{a}}$ & $\mathscr{\delta}$ & $\stackrel{\curvearrowright}{ヘ}$ & & & & & & & & & & & & & & 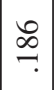 & $\frac{\infty}{0}$ & \\
\hline ڤ่̊ & in. & $\stackrel{\infty}{\stackrel{f}{f}}$ & $\stackrel{m}{f}$ & $\hat{\alpha}$ & है & $\bar{n}$ & $\frac{\infty}{\infty}$ & 赵 & m̂n & $\begin{array}{l}n \\
\infty \\
\infty\end{array}$ & 8 & ले & 8 & - & $\begin{array}{l}8 \\
\stackrel{0}{n}\end{array}$ & $\frac{\nabla}{\sigma}$ & $\widehat{\widehat{\sigma}}$ & \\
\hline & 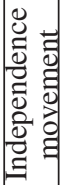 & 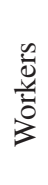 & 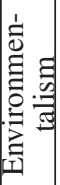 & 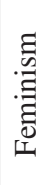 & 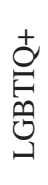 & 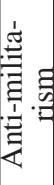 & 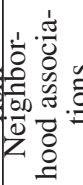 & 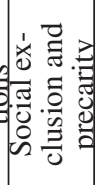 & 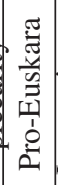 & 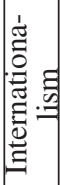 & 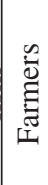 & 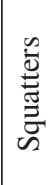 & 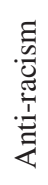 & 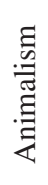 & 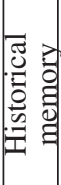 & $\frac{0}{\tilde{z}}$ & 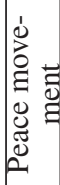 & 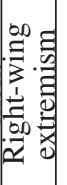 \\
\hline
\end{tabular}




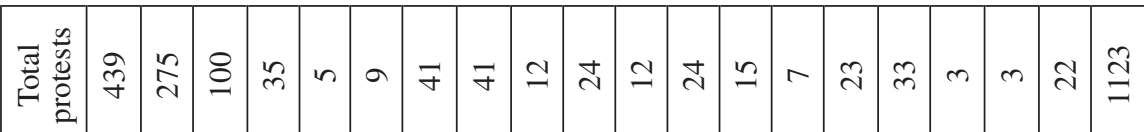
文司氧。 6 v -

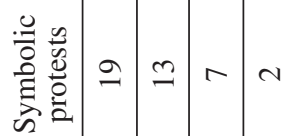

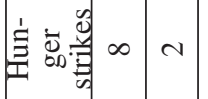

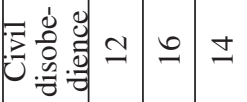

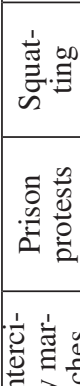
焉

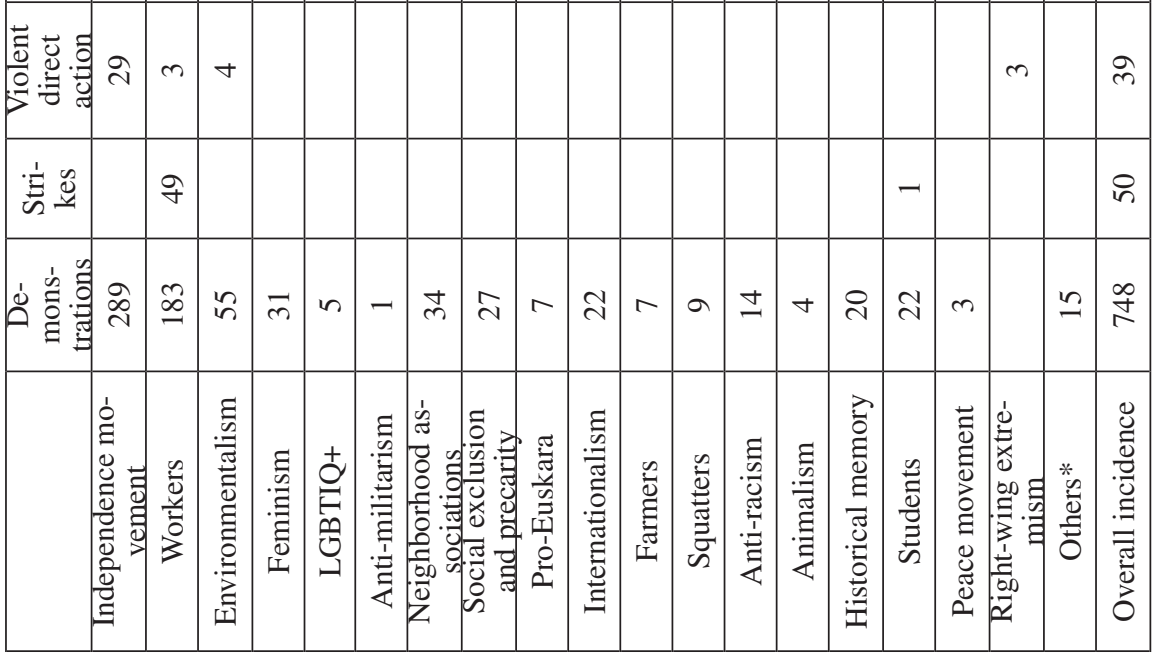


A. CIORDIA Y A. LETAMENDIA I USING SOCIAL NETWORK ANALYSIS TO STUDY ... 93

\begin{tabular}{|c|c|c|c|c|c|c|c|c|c|c|c|c|c|c|c|c|c|c|}
\hline 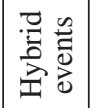 & $\stackrel{ \pm}{0}$ & & 8 & & & & g) & $\stackrel{\Xi}{\Delta}$ & & & $\tilde{O}$ & & $\hat{8}$ & & & లి & & \\
\hline 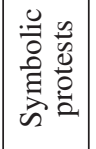 & fo & 守 & 옹 & n. & & 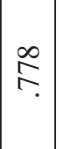 & đ̦ & તิ & $\stackrel{\Xi}{\ni}$ & I & $\begin{array}{l}\stackrel{\overbrace{}}{n} \\
\end{array}$ & $\stackrel{?}{\simeq}$ & & શे. & & & & \\
\hline 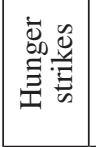 & $\frac{\infty}{0}$ & $\hat{8}$ & & & & & & & & & & $\mathscr{\infty}$ & & & & & & \\
\hline 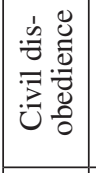 & స్ర. & $\begin{array}{l}\infty \\
\wp \\
c\end{array}$ & $\stackrel{\text { 巳 }}{ \pm}$ & & & & $\overleftrightarrow{\Xi}$ & $\stackrel{\infty}{8}$ & & & $\mathscr{\infty}$ & $\mathscr{\infty}$ & & & & $\underset{\infty}{\infty}$ & & \\
\hline 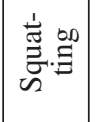 & & & ฮิ & & & & & & & & & 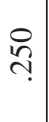 & & & & & & \\
\hline 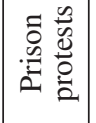 & $\underline{0}$ & & & & & & & & & & & & & & & & & \\
\hline 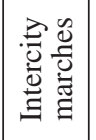 & : & ڤె. & 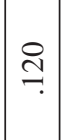 & n. & & $\exists$ & ڤ. & & & $\stackrel{T}{O}$ & & $\begin{array}{l}0 \\
\infty \\
0\end{array}$ & & & $\begin{array}{l}0 \\
\stackrel{n}{\longrightarrow}\end{array}$ & $\bar{a}$ & & \\
\hline 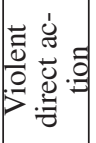 & 0 & $\vec{a}$ & ㅇ. & & & & & & & & & & & & & & & - \\
\hline$\stackrel{1}{\Xi} \stackrel{\mathscr{Q}}{\mathscr{E}}$ & & $\stackrel{\infty}{=}$ & & & & & & & & & & & & & & ల్ & & \\
\hline 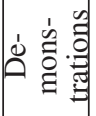 & $\begin{array}{l}\infty \\
0 \\
6 \\
0\end{array}$ & ?ֶ. & $\begin{array}{l}\stackrel{0}{n} \\
\text { nn }\end{array}$ & $\begin{array}{l}0 \\
\infty \\
\infty \\
\infty\end{array}$ & - & 三 & సે & ڤ్రి & $\begin{array}{l}n \\
\ddot{n} \\
\end{array}$ & $\frac{\bar{\sigma}}{a}$ & $\begin{array}{l}m \\
\infty \\
n\end{array}$ & $\frac{n}{n}$ & $\widetilde{\sigma}$ & $\vec{n}$ & $\begin{array}{c}P \\
\infty \\
\infty\end{array}$ & రి & - & \\
\hline & 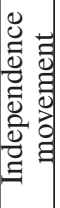 & $\begin{array}{l}0 \\
\frac{2}{0} \\
\frac{1}{0} \\
3 \\
3\end{array}$ & 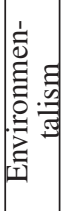 & 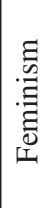 & 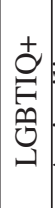 & 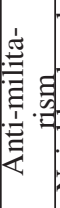 & 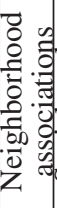 & 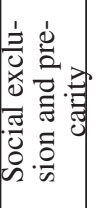 & 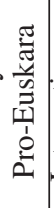 & 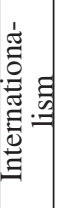 & 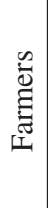 & 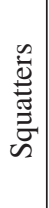 & 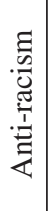 & 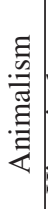 & 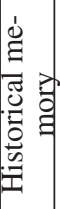 & 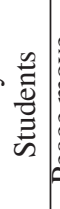 & 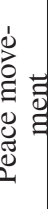 & 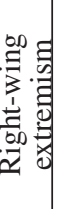 \\
\hline
\end{tabular}




\begin{tabular}{|c|c|c|c|c|c|c|c|c|c|c|c|c|c|c|c|c|c|c|c|}
\hline 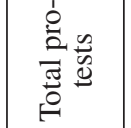 & $\vec{m}$ & ঃ্ల & $n$ & \& & $N$ & $\infty$ & $\approx$ & 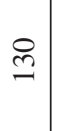 & I & $a$ & $N$ & 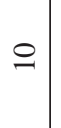 & $\stackrel{\infty}{-}$ & $N$ & $\Xi$ & f & $m$ & $\infty$ & $\stackrel{\infty}{\stackrel{0}{O}}$ \\
\hline 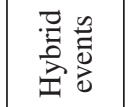 & $\infty$ & - & $N$ & & & & & & - & - & - & & - & & - & - & & & 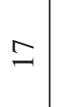 \\
\hline 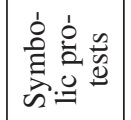 & $\curvearrowleft$ & $\stackrel{\infty}{\sim}$ & 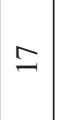 & 0 & & $m$ & $N$ & ৯े & $\nabla$ & $N$ & - & $m$ & $m$ & - & $m$ & $\nabla$ & & $N$ & $\cong$ \\
\hline 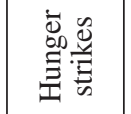 & $m$ & -1 & & & & & & & & & & & & & & - & & & $n$ \\
\hline 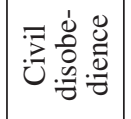 & $a$ & $\approx$ & $N$ & & & & - & $=$ & & & & - & & & & $n$ & & & $\dot{n}$ \\
\hline $\begin{array}{l}\stackrel{1}{\tilde{\Xi}} \text { on } \\
\overrightarrow{\tilde{E}} \cdot \Xi\end{array}$ & & & & & & & & & & & & $\nabla$ & & & & & & & $\nabla$ \\
\hline 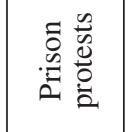 & 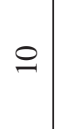 & & & & & & & & & & & & & & & & & & $\stackrel{ }{-}$ \\
\hline 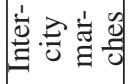 & $\simeq$ & 6 & $m$ & $N$ & & - & - & 0 & $N$ & & & & - & & & & & & ఉా \\
\hline 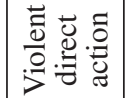 & $\forall$ & 0 & - & & & & & - & & & & & & & & - & $N$ & & $\cong$ \\
\hline 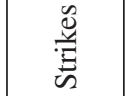 & & $\triangleright$ & & - & & & & & & & & & & & & $r$ & & & $\infty$ \\
\hline 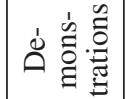 & $\frac{m}{\sim}$ & gి & ষ্ল & $\vec{m}$ & $N$ & $\nabla$ & $\vec{\sim}$ & $\infty_{\infty}$ & 으 & 0 & & $N$ & 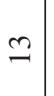 & - & 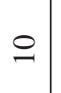 & 고 & - & 0 & 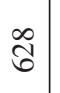 \\
\hline & 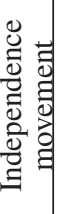 & $\begin{array}{l} \\
\frac{0}{0} \\
\frac{0}{0} \\
3 \\
3\end{array}$ & 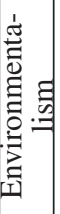 & 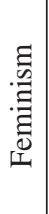 & 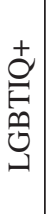 & 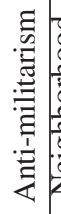 & 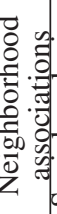 & 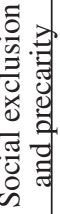 & 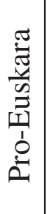 & 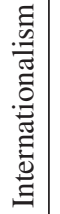 & 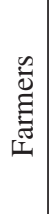 & 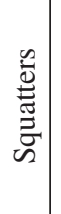 & 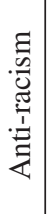 & 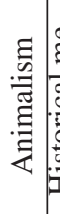 & 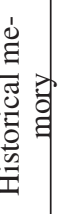 & 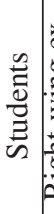 & 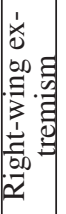 & 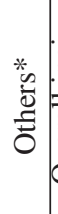 & 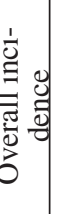 \\
\hline
\end{tabular}


A. CIORDIA Y A. LETAMENDIA USING SOCIAL NETWORK ANALYSIS TO STUDY ... 95

\begin{tabular}{|c|c|c|c|c|c|c|c|c|c|c|c|c|c|c|c|c|c|}
\hline 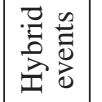 & ذ্ّ & $\tilde{\delta}$ & $\begin{array}{l}0 \\
\text { ల్ర }\end{array}$ & & & & & & ชิ & $\exists$ & $\begin{array}{l}8 \\
n \\
n\end{array}$ & & ஜ̊ & & $\bar{\delta}$ & ฮิ & \\
\hline 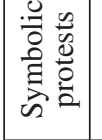 & તิ & ถે & ஜे & $\stackrel{\circ}{?}$ & & $\stackrel{n}{n}$ & $\stackrel{0}{\infty}$ & તิ & થิ & ָิ & 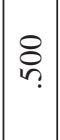 & ৪্ & $\hat{0}$ & 8 & $\stackrel{\nabla}{\sim}$ & $\stackrel{\circ}{0}$ & \\
\hline 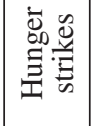 & $\hat{8}$ & $\hat{8}$ & & & & & & & & & & & & & & ปิ & \\
\hline 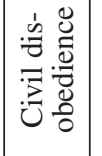 & ડิ & $\begin{array}{l}\text { o } \\
\infty\end{array}$ & లి & & & & \& & $\mathscr{\infty}$ & & & & 8 & & & & $\exists$ & \\
\hline $\begin{array}{l}\stackrel{\infty}{\Xi} \\
\stackrel{\Xi}{E} \\
\stackrel{\Xi}{E} \\
\mathscr{E}\end{array}$ & & & & & & & & & & & & \& & & & & & \\
\hline 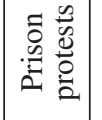 & ల్లి & & & & & & & & & & & & & & & & \\
\hline 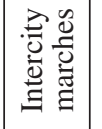 & ల్లి & ๙ิ & हn & ஜn & & $\stackrel{2}{I}$ & 옹 & ర) & $\stackrel{\infty}{=}$ & & & & ஜ̊ & & & & \\
\hline 节 & $\frac{2}{0}$ & ڤ్ & $\stackrel{\infty}{\sigma}$ & & & & & $\stackrel{8}{8}$ & & & & & & & & ปิ & $\overline{8}$ \\
\hline 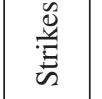 & & 뭉 & & ฮె & & & & & & & & & & & & $\stackrel{\circ}{n}$ & \\
\hline 施 & $\underset{\widetilde{\sigma}}{\infty}$ & ñ & $\stackrel{n}{n}$ & $\stackrel{n}{\stackrel{2}{f}}$ & - & 8 & ஒ & $\underset{\widetilde{ర}}{\infty}$ & $\mid \begin{array}{l}\infty \\
\infty \\
\infty\end{array}$ & 웅. & & §্ণ & $\stackrel{\mathbb{N}}{\mathrm{N}}$ & 8 & $\stackrel{\Xi}{\nabla}$ & $\frac{\infty}{n}$ & $\stackrel{m}{m}$ \\
\hline & 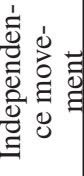 & $\begin{array}{l}0 \\
\frac{0}{0} \\
\frac{2}{0} \\
3\end{array}$ & 诖 & 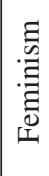 & 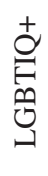 & 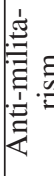 & 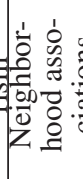 & 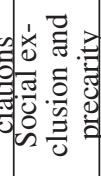 & 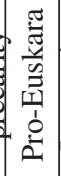 & 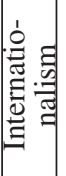 & 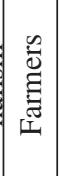 & 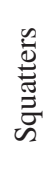 & 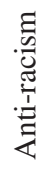 & 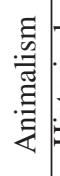 & 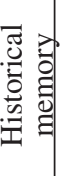 & 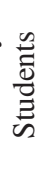 & 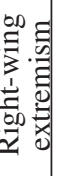 \\
\hline
\end{tabular}


